Cahiers $d u$ MONDE RUSSE

\section{Cahiers du monde russe}

Russie - Empire russe - Union soviétique et États indépendants

$43 / 1 \mid 2002$

Varia

\title{
Production and terror: The operation of the Karelian Gulag, 1933-1939.
}

Nick BARON

\section{OpenEdition}

\section{Journals}

Édition électronique

URL : https://journals.openedition.org/monderusse/8487

DOI : 10.4000/monderusse.8487

ISSN : $1777-5388$

Éditeur

Éditions de l'EHESS

Édition imprimée

Date de publication : 1 janvier 2002

Pagination : 139-180

ISBN : 2-7132-1773-3

ISSN : $1252-6576$

Référence électronique

Nick BARON, "Production and terror: The operation of the Karelian Gulag, 1933-1939. », Cahiers du monde russe [En ligne], 43/1 | 2002, mis en ligne le 01 janvier 2007, consulté le 02 septembre 2022 URL : http://journals.openedition.org/monderusse/8487 ; DOI : https://doi.org/10.4000/monderusse. 8487 
chercher : repérer : avancer

Cet article est disponible en ligne à l'adresse :

http://www.cairn.info/article.php?ID REVUE=CMR\&ID NUMPUBLIE=CMR 431\&ID ARTICLE=CMR 4310139

Production and terror: The operation of the Karelian Gulag, 1933-1939

\author{
par Nick BARON
}

Editions de l'EHESS | Cahiers du monde russe

$2002 / 1$ - Vol 43

ISSN 1252-6576 | ISBN 2713217733 | pages 139 à 180

Pour citer cet article :

-BARON N., Production and terror: The operation of the Karelian Gulag, 1933-1939, Cahiers du monde russe 2002/ 1 , Vol 43, p. 139-180.

Distribution électronique Cairn pour les Editions de l'EHESS.

(C) Editions de l'EHESS. Tous droits réservés pour tous pays.

La reproduction ou représentation de cet article, notamment par photocopie, n'est autorisée que dans les limites des conditions générales d'utilisation du site ou, le cas échéant, des conditions générales de la licence souscrite par votre établissement. Toute autre reproduction ou représentation, en tout ou partie, sous quelque forme et de quelque manière que ce soit, est interdite sauf accord préalable et écrit de l'éditeur, en dehors des cas prévus par la législation en vigueur en France. Il est précisé que son stockage dans une base de données est également interdit. 


\section{PRODUCTION AND TERROR: THE OPERATION OF THE KARELIAN GULAG, 1933-1939*}

\section{Introduction}

This is the second of two papers surveying the origins, expansion and operation of the Soviet 'special' camp system in the Karelian Autonomous Republic (ASSR) between 1923 and 1939. Together, they offer an extended and detailed empirical case study of the development of the Gulag at regional level.

In the first paper, I considered the growth of the Unified State Political Administration (the political police, OGPU) camp system in Karelia, from the founding of the Solovetskii Camp of Special Designation (SLON) in 1923 to the completion of the Belomorsko-Baltiiskii (Belomor) Canal in 1933.1 The OGPU's experience of managing SLON for the isolation and economic exploitation of prisoners encouraged the Soviet authorities in the late 1920's to formulate ambitious plans for the penal colonisation and development of the Soviet North, explicitly on the "Solovetskii model."2 The Belomor Canal construction in 19311933 was an important stage of this project, because it seemingly enabled the OGPU to demonstrate its capacity, at minimal cost to the state budget, to complete major tasks of economic and strategic significance.

* I am grateful to the UK Economic and Social Research Council for funding my research on Soviet Karelia, and to Bob Davies, Andrea Graziosi and Peter Gatrell for their comments on drafts of this work.

1. Nick Baron, "Conflict and complicity: The expansion of the Karelian Gulag, 1923-1933," Cahiers du Monde russe, 42, 2-3-4 (April-December 2001): 615-648.

2. Proposal by People's Commissariat of Justice (NKIust), People's Commissariat of the Interior (NKVD) and OGPU for use of prison labour in the national economy, 13 April 1929, reproduced in S. A. Krasil nikov, ed., "Rozhdenie GULAGa: Diskussii v verkhnikh eshelonakh vlasti," Istoricheskii arkhiv, 4 (1997): 144, cited in Philip Boobbyer, The Stalin era (London: Routledge, 2000): 53. 
Two weeks after the official opening of the Belomor Canal in central Karelia, a Politbiuro commission headed by V. V. Kuibyshev resolved to charge the OGPU with establishing a large industrial complex, the Belomorsko-Baltiiskii Kombinat (BBK), on territory adjoining the canal. ${ }^{3}$ The BBK, which in 1934 passed with the whole Gulag system to the jurisdiction of the new All-Union People's Commissariat of Internal Affairs (NKVD), is the focus of this second paper. Since I have examined elsewhere the BBK's role in regional planning and development, this paper considers the camp's productive activities, as well as its repressive operations, primarily in relation to its interactions with other regional authorities, and to its internal procedures of control and discipline. 4

\section{The BBK economy: ambitions and reality}

A 17 August Union Sovnarkom decree assigned the BBK the task of developing and exploiting the economic potential of the Belomor Canal and the timber resources along its banks.5 The BBK also inherited the Solovetskii camp's operations along the White Sea littoral (north and south of Kem') and on the Kola Peninsula as far north as the Arctic coast. The Combine was freed from taxes until 1936, and granted the rights - and obligations - of financial autonomy (khozrashchet) on the model of the Solovetskii administration. A month later, the BBK issued its own statement of purpose, which declared that:

"In an exceptionally short period the BBK OGPU must fulfil the gigantic work of assimilating and exploiting the natural resources of Karelia and putting to maximum use those wide opportunities which the Belomorsko-Baltiiskii Water Route (BBVP) opens for the region, must create a series of new large-scale hydrotechnical installations, hydroelectric power stations and industrial enterprises, develop mining and extraction of mineral resources, construct socialist towns etc." 6

3. The 15 August Politbiuro meeting also agreed to consider deepening and widening the canal to permit proper military usage (in order to cut costs, the OGPU had cut the first channel too shallow for naval vessels), Russian State Archive of Socio-Political History (Rossiiskii Gosudarstvennyi Arkhiv Sotsial'no-Politicheskoi Istorii - RGASPI, former party archive), f. 17 , op. 3 , d. $928,1.24$. This project was superseded by the more feasible and cheaper project of building a second canal, running alongside the first. This, however, was never implemented, see lurii Kilin, "BBK kak faktor voennoi strategii," Sever, 7 (1995): 111-112.

4. Nick Baron, "The Karelian ASSR: Spatial paradoxes of Stalinist power," in E. A. Rees, ed., Centre-local relations in the Second Five-Year Plan (London: Macmillan, 2002) and Nick Baron, "Soviet Karelia, 1920-1937. A study of space and power in Stalinist Russia," doctoral thesis submitted to the University of Birmingham, 2001, especially Chapter Five.

5. National Archive of the Karelian Republic (Natsional'nyi Arkhiv Respubliki Kareliia - NA RK, formerly TsGARK), f. 865, op. 36, d. 1, 11. 35-36.

6. NA RK, f. 865 , op. 1, d. 51, 11. 190-191, also in A. Iu. Zhukov, V.G. Makurov, 1. G. Petukhova, eds., Gulag $v$ Karelii. Sbornik dokumentov i materialov 1930-1941 (Petrozavodsk: Karel'skii Nauchnyi Tsentr, Russian Academy of Sciences, 1992): 91. 
Despite their mutual suspicions, the OGPU-NKVD and Karelian authorities had a common interest in promoting regional development. Both believed that Karelia's future lay in developing energy resources and utilising new transport opportunities as the basis for extensive and complex industrial construction, transforming the regional economy from one based solely on "timber supply and sawing into highlydifferentiated branches of production."7

In April 1934, therefore, Karelian and BBK officials and experts (many of whom were prisoners) convened to discuss a project to divert and dam a number of central Karelian rivers. This would boost the canal zone's hydroenergy generating potential, enabling the BBK to undertake the construction on its territory of chemical and metallurgical plants, including factories for the manufacture of aluminium, vanadium, sulphuric acid and synthetic rubber. The BBK's full programme of investment required 514.6 million rubles. ${ }^{8}$ This sum, it should be noted, was equivalent to $80 \%$ of the Second Five-Year Plan's total envisaged investment in Karelia.?

While the Karelian government and BBK agreed on a general scheme of regional development, there were two specific divergences of interest. Firstly, the Combine was concerned only with the economy of the canal zone. Therefore, it opposed Karelian plans to develop an aluminium factory in Kandalaksha, in the north of the autonomous republic, arguing instead for its own aluminium factory adjacent to the canal. ${ }^{10}$ The BBK submitted a request to Moscow for 51.7 million rubles for this project: the petition was accepted, but the Second Five-Year Plan draft allocated only 30 million rubles, and the construction was later abandoned when the centre refused to release even this sum (see below). ${ }^{11}$

Secondly, the Karelians wanted new industry in order to stimulate the development of local raw materials, and saw the new water system as an opportunity primarily to increase the region's export freight capacity to the Leningrad port and the Russian interior. The BBK's conception of Karelia's role was self-professedly far more "grandiose" in scope." In its view, the Belomor

7. See Project "Plan of prioritisation of hydroelectricity construction and the development of industry in the BBK raions," Leningrad Bureau of the BBK NKVD, 1 May 1935, NA RK, f. 700, op. 1, d. 197-1425,1.22. For a detailed analysis of BBK and Karelian economic plans in this period, see N. Baron, "Soviet Karelia, 1920-1937," op. cit.: Chapters Four and Five.

8. Stenogram of BBK meeting with Karelian leader Edvard Gylling, 20 April 1934, NA RK, f. 520, op. 1, d. 28, 11. 1-22. See also Project "Plan of prioritisation," NA RK, f. 700, op. 1, d. 197-1425,1.21; A. A. Kolpakov, "Energeticheskoe ispol'zovanie vodnykh resursov srednei Karelii," Belomorsko-Baltiiskii Kombinat, 5 (1935): 3-6.

9. Vtoroi piatiletnii plan razvitiua narodnogo khoziaistva SSSR (1933-1937 gg). T. II. Plan razvitiia raionov (Moscow: Partizdat, 1934): 19-22.

10. See BBK's Project "Plan of prioritisation," NA RK, f. 700, op. 1, d. 197-1425,1.4.

11. Proekt vtorogo piatiletnego plana razvitiia narodnogo khoziaistva SSSR (1933-1937), T. II. Plan razvitiia raionov (Moscow: Partizdat, 1934): 18, 310.

12. OGPU document, probably 1933, State Archive for Socio-Political Movements and Formations of the Karelian Republic (Gosudarstvennyi Arkhiv Obshchestvenno-Politicheskikh Dvizhenii i Formirovanii Respubliki Kareliia - GAOPDF RK, former party archive, ), f.3, op. 3, d. 118-39, 1.9. 
Canal would transform central Karelia into a major transport "hub" (uzel) uniting the newly opened Arctic passage with reconstructed internal waterways and global sea routes. In particular, Karelia could act as the "gateway of the North," and a "major industrial-processing centre for incoming raw materials," extracted in the forced labour camps of the Arctic (such as those in Pechora, Vaigach and Novaia Zemlia) and the Far East. ${ }^{13}$ The BBK modestly defined its objective "geographically to combine the materials, fuel and energy of the whole region on the model of the Urals-Kuznetsk Combine ..." Almost as an afterthought, it added "... on a smaller scale." 14

The BBK waited in vain for the Soviet centre to assign funds to realise this vision. The central government did not consider Karelia a suitable site for largescale industrial development, primarily because of its strategic vulnerability on the state border. Furthermore, the Second Five-Year Plan reoriented investments towards consumer goods and agriculture, which disadvantaged new industrial projects in low priority sectors or regions. On the Gulag line, the bulk of capital investment went to the Arctic and Far Eastern camps, especially for the construction of the Baikal-Amur Railway. ${ }^{15}$ To some extent, the BBK was also a victim of its own seeming success in the labour-intensive canal project. In mid1935, Union Gosplan stated that using the camp's forced labour for felling offered the possibility of "significant results with relatively insignificant capital investment" and proposed expanding its timber operations. ${ }^{16}$ In other words, if Gulag labour was so productive in felling and basic construction activities, why give it money for complex, intensive industrial development? On this principle, the Second Five-Year Plan allocated funding to the BBK for construction of a new timber processing combine at Segezha, the Tulomskaia hydroelectricity plant on the Kola Peninsula and an aluminium plant in Matkozha, but made no provisions for any other of its major planned objects. When the BBK protested that its metallurgical factory would not be able to function without additional hydroenergy construction, the People's Commissariat of Heavy Industry (Narodnyi Komissariat Tiazheloi Promyshlennosti - NKTP) accepted the logic of the argument, and struck the factory also from its list of investment objects. ${ }^{17}$

13. For these operations, see M. B. Smirnov, ed., Sistema ispravitel'no-trudovykh lagerei $v$ SSSR, 1923-1960. Spravochnik (Moscow: Zven ia, 1998): 379-380, 497-499, 179-180, 208 209 .

14. Project "Plan of prioritisation," NA RK, f. 700, op. 1, d. 197-1425, 11.3, 22-24.

15. Bamlag grew fastest, see V. N. Zemskov in V. B. Zhiromskaia, ed., Naselenie Rossii $v$ XX veke. Istoricheskie ocherki. T. 1. 1900-1939(Moscow: Rosspen, 2000): 315.

16. Letter to Molotov, 13 May 1935, State Archive of the Russian Federation (Gosudarstvennyi Arkhiv Rossiiskoi Federatsii - GA RF), f. 5446, op. 16a, d. 1330, 1. 5.

17. Leningrad BBK Bureau "Theses for plan of electrical development in Central Karelia," 9 January 1935, NA RK, f. 865, op. 41, d. 63-753, 11. 1-3. See also Leningrad BBK Bureau "Explanatory notes on planned hydroelectricity construction in the BBK region," NA RK, f. 865 , op. 41 , d. $63 / 756$. 
In June 1935, the BBK warned aggrievedly that "the sharp reduction in capital investment in the BBK for 1935 will not permit work to be continued in this year at such tempos [...] as will ensure realisation of all tasks given to the Combine by the party and government on its establishment." 18 In 1936, the BBK again failed to obtain its requested allocations. ${ }^{19}$ A BBK report in early 1937 stated conclusively that "there has been no serious capital investment to resolve the task of assimilating the region," and requested a minimum of 750-800 million rubles funding for the Third Five-Year Plan. ${ }^{20}$ The BBK had apparently not yet given up its ambitious visions.

In the meantime, the BBK was forced, by default, to specialise in timber felling and processing. In 1933, the Karelian government was instructed to concede to the camp several timber factories and vast swathes of forest in its central districts. ${ }^{21}$. Two years later Karelia had not yet relinquished this territory, so the Union Sovnarkom issued a decree confirming the Combine's status as one of the region's "basic timber organisations," with sole rights of exploitation over nearly 30,000 square kilometres of central Karelian forest. ${ }^{22}$ This area was equivalent to a fifth of the total regional timber fund..$^{23}$ By 1936 , BBK operations accounted for nearly a quarter of Karelian felling output and in 1937 the camp produced over a third of all the autonomous republic's felled timber. ${ }^{24}$ The BBK in this year employed over $60 \%$ of its prisoners in felling and associated activities..$^{25}$ Overall, BBK felling output in 1937, together with its manufacture of sewn garments and leather goods (on which it employed weak and female prisoners, comprising about $10 \%$ of its population), accounted for nearly $30 \%$ of total republican output by value. ${ }^{26}$ The camp was also engaged in strategically significant road construction and in

18. From Resolutions of the First Party Conference of the BBK NKVD, 21-23 June 1935 (Medvezh'egorsk: Izd. Partiinogo Komiteta BBK NVD, 1935), GAOPDF RK, f. 38, op. 1, d. 1, $11.33 \mathrm{ob}-34$.

19. The bulk of Gulag funding went to the Moscow-Volga Canal construction, see NKVD titular lists for 1936, June 1936, GA RF, f. 5446, op. 18a, d. 637, 11.212, 215.

20. Report on the activities of the BBK Raikom, April 1937, GAOPDF RK, f. 38, op. 1, d. 10,1. 100.

21. See Karplan memo on "Development of the timber industry in relation to the opening of the Belomor Canal," Russian State Archive of the Economy (Rossiiskii Gosudarstvennyi Arkhiv Ekonomiki - RGAE), f. 4372, op. 32, d. 776a, 11.2-3.

22. Decree "On timber territory of the BBK," 10 July 1935, NA RK, f. 865, op. 36, d. 1, 1. 2. The BBK received three timber-industrial enterprises (lespromkbozy) immediately in 1935 (Report of BBK NKVD for 1935, in GA RF, f. 9414, op. 1a, d. 761, 11.2, 37), but Karelia again delayed in transferring the remainder of the designated timber areas to the BBK until 1938 1939.

23. RGAE, f. 4372 , op. 32, d. 776a, 11. 1-4.

24. "Results of the Karelian Second Five-Year Plan," 1938-1939, NA RK, f. 700, op. 1, d. $212-$ $1558,11.27,48-51$. For a more detailed analysis of these data, see N. Baron, "Soviet Karelia, 1920-1937," op. cit.: Chapter Five.

25. Calculated from BBK structure as of 1 January 1938, NA RK, f. 865, op. 32, d. 1/8, 1. 38, reproduced also in A. Iu. Zhukov et al., eds., Gulag v Karelii..., op. cit.: 147.

26. Calculated from Karelian statistical report, presented after January 1941, NA RK, f. 1411, op. 2, d. 360, 11. 10-11, reproduced in L. I. Vavulinskaia, ed., Narodnoe khoziaistvo Karelii, 1926 g. - iun' 1941 g. Dokumenty i materialy (Petrozavodsk: Kareliia, 1991): 27. 
maintaining canal operations. Since the BBK was of such importance in the regional economy, it was important that co-operative relations were maintained between the camp administration and the republican authorities.

\section{BBK's relations with regional authorities}

According to the BBK's founding decree, the Combine would operate independently of Karelian republican authority, but should agree its economic plans with the Karelian Sovnarkom before submitting them via OGPU headquarters in Moscow to Union Gosplan. The necessity of working together, however, did little to improve relations between the secret police and soviet officials.

In late 1935, Soviet diplomat E. A. Asmus, who had just completed a tour of Karelia, reported to People's Commissar of Foreign Affairs M. M. Litvinov that "there is a feeling that Karelian comrades consider the BBK to be alien and foreign (chuzhim $i$ chuzherodnym) instead of being proud of it and benefiting from its experience." He contrasted the BBK's "dazzling scope" and "enthusiasm for construction" (pafos stroitel'stva) with the shoddy state and limited visions of Karelian industry. As examples of the Karelian attitude, he cited the republican government's refusal to make full use of the BBK's workforce in their regional economy, and its failure to include BBK statistics in its plans. ${ }^{27}$

The Karelian authorities, in fact, were intensely aware of the need to collaborate with the BBK. As early as October 1933, they issued a decree proposing measures to establish "businesslike relations, reciprocal information exchange and the regulation of current questions." 28 Their attempt to develop a working relationship, however, elicited no response from the assertive and independent-minded local Chekists. In February 1934, the Karelian Gosplan complained about the impossibility of formulating its own economic programmes when the agency received no information from the BBK's Planning-Economic Department. ${ }^{29}$ The Karelians were still complaining about BBK secrecy in May 1937, when the Combine's leader Z. A. Almazov retorted disingenuously to the regional party conference that:

"Some Karelian organisations - Gosplan and others - get offended by the BBK, but why is it important for them to know how many prisoners we have? And yet still they ask us 'How many prisoners do you have?' and I reply '[...] You don't need to know, it isn't interesting." "30

27. Report dated 5 November 1935, Foreign Policy Archive of the Russian Federation (Arkhiv Vneshnei Politiki Rossiiskoi Federatsii - AVP RF), f. 05, op. 15, d. 110-92, 1. 69.

28. NA RK, f. 865 , op. 36, d. 1,1.13.

29. NA RK, f. 690 , op. 3, d. 613, 11. 15-18.

30. RGASPI, f. 17, op. 21, d. 1914,1. 187. 
The Karelian government, of course, well understood the extent to which the regional timber economy depended upon the BBK's workforce, having experienced the consequences of its absence. In March 1934, the regional party chief Kustaa Rovio received a coded telegram from Leningrad boss S. M. Kirov demanding that all prisoners be removed within twenty-four hours from timber factories, felling sites and transport activities along the Murmansk railway line (probably because a foreign inspection team was expected - there had been regular visits since the 1930 western boycott of Soviet timber exports). ${ }^{31}$ A day later, the Karelian Second Secretary A. M. Apolonik reported to Kirov that most of the 10,000 prisoners working on contract to regional economic organisations had been replaced, by redistributing the free workforce from other activities and mobilising their families, so that "all traces of the activities of prisoners have been externally disguised." He added urgently, however, that Karelian civil agencies could not provide sufficient labour to compensate for the removal of prisoners, and Leningrad organisations had failed to respond to their requests. The result was that "people here are in despair from the thought that the felling plan this year will definitely collapse."32

Karelia's reliance on the BBK for contract labour was dangerous for other reasons. Since its establishment in January 1932, the People's Commissariat of the Timber Industry (Narkomles), which controlled the Karelian timber trust Karelles, had been under-funded and grossly mismanaged. In May 1934, the Head of Karelles wrote to Apolonik reporting that because Narkomles had failed to remit four million rubles in recent months to the republican trust, it now owed over 1.5 million rubles in wage arrears. The Deputy of Narkomles A. K. Al'bert had been appraised of the situation and had sent a telegram to the People's Commissar S. S. Lobov reporting that "the financial state of Karelles is catastrophic." As a result, the Karelian agency was unable to recruit free labour, and it had to purchase all supplies on credit. Current workers were quitting their jobs or refusing to work. The worst news, however, was that because Karelles had now accumulated a debt to the BBK of over 750,000 rubles, the Combine had removed all prisoners working for the civil agency until this debt was cleared. Its action had led to a collapse of production in at least two timber-industrial enterprises (lespromkhozy). ${ }^{33}$

Concerned by the extent to which the BBK asserted its autonomy from regional authorities, the Karelian administration continued its efforts to constrain Chekist conduct by means of party discipline. Within two weeks of the BBK's establishment, the Karelian party organisation co-opted the camp chief Ia. D. Rapoport as a member of the Obkom bureau ${ }^{34}$ Rapoport proposed that party members among the dispersed BBK camp network, currently co-ordinated merely by a Political Department

31. On the boycott and earlier prisoner evacuations, see N. Baron, "Soviet Karelia, 19201937," op. cit.: Chapter Four.

32. Letter from Apolonik to Kirov, 9 March 1934, GAOPDF RK, f. 3, op. 3, d. 130-173, 1.9.

33. Memorandum, 20 May 1934, GAOPDF RK, f. 3, op. 3, d. 130-173, 11. 36-37.

34. Protocol of Karelian Obkom bureau, 29 August 1933, RGASPI, f. 17, op. 21, d. 1953, 1. 250 . 
(Politotdel) in the central administration, should be unified under a committee with the rights of a raikom, and agreed that this should be subordinated to the Karelian Obkom. ${ }^{35}$ The Leningrad Obkom, however, refused to ratify this proposal as it wished to retain the BBK party organisation directly under its own authority. In spring 1935, Rapoport visited Central Committee (TsK) Secretary G. M. Malenkov, who was in the Karelian capital Petrozavodsk conducting an investigation of the local party's verification (proverka) of party documents. ${ }^{36}$ Malenkov's subsequent intervention against Leningrad leader A. A. Zhdanov seems to have been decisive. On 20 June, the TsK's Organisational Bureau (Orgbiuro) permitted the BBK to organise a party committee 'with the rights of a raikom,' subordinate to the Karelian Obkom. ${ }^{37}$ Within a few months of this decision, however, Zhdanov removed Edvard Gylling and his Finnish associates from the Karelian leadership, replacing them with his own officials. As the Karelian party became an adjunct of the Leningrad organisation, BBK officials became increasingly subject to party regulation ("earlier, we had been Chekists first, and Communists only second," recalled a camp official two years later $)^{38}$ and, conversely, the NKVD drew the party into its campaign against the judicial authorities, as we shall see later.

Finally, in July 1936, the TsK agreed to promote the BBK's party committee to full raikom status. ${ }^{39}$ As of 1 January 1937, the BBK Raikom comprised twenty-four Primary Party Organisations (PPO's) and thirteen primary party committees (i.e. one unit for each territorial section, lespromkhoz and division of guards) ${ }^{40}$ totalling 342 party members, 131 candidates, 390 komsomol members and no less than 8,342 pioneers (almost all the children of labour settlers were automatically enrolled). ${ }^{41}$

\section{The BBK population}

The BBK's party organisation was based on its administrative-territorial structure which it inherited almost unchanged from A. P. Nogtev's 1930 reorganisation of the Solovetskii camp (for details, see the earlier paper). ${ }^{42}$ The Combine comprised

35. GAOPDF RK, f. 214 , op. 1, d. 13a, 11. 160-161.

36. Memorandum, 24 April 1935, GAOPDF RK, f. 214, op. 1, d. 13a, 1. 173.

37. Protocol 31 of TsK Orgbiuro, RGASPI, f. 17, op. 114, d. 587,1. 16.

38. Stenogram of Thirteenth Karelian Obkom Conference, May 1937, RGASPI, f. 17, op. 21, d. $1914,1.230$.

39. GAOPDF RK, f. 38 , op. 1 , d. $1,1.45$.

40. BBK Raikom report, 30 December 1936, GAOPDF RK, f. 38, op. 1, d. 5, 11. 255-256, also published in A. Iu. Zhukov et al., eds., Gulag v Karelii..., op. cit.: 134-36.

41. Notes for First BBK Raikom Conference, 4 September 1936, GAOPDF RK, f. 38, op. 1, d. 1, 11. 74-77.

42. Directive on Sections of the BBK, 13 October 1934, NA RK, f. 865, op. 32, d. 3,11. 10-20. 
around twenty territorial Sections (otdeleniia), stretching from southern Karelia to Murmansk, each sub-divided into camp points (otdel'nye lagernye punkty) and mobile labour 'columns' for prisoners working at different locations within a district, plus a number of 'special settlements' for kulak exiles. ${ }^{43}$ The BBK also administered a Youth Colony at Nadvoitsy and a sovkhoz near Povenets. Some of these Sections, for example Segezhstroi, were at times directly subordinated to the NKVD Gulag in Moscow. The structure of the central BBK administration in Medvezh ia Gora (later renamed Medvezh'egorsk) was also based on SLON's organisation, and comprised 22 departments in 1935 (increasing to 36 in late 1939), each of which was represented by a sub-department in each Section. The administration employed both free workers and prisoners: in the First (Medvezh'egorsk) Section, for example, 129 out of 200 employees were prisoners. 44

\subsection{The 'special settlers'}

The BBK's 17 August 1933 founding decree had directed it not only to develop the economy of the canal zone of central Karelia, but also to colonise it, primarily by the settlement of labour exiles. ${ }^{45}$ The BBK's own directive of 10 September stated that it would populate the "great spaces" along the canal with both 'special settlers" and with prisoners released at the end of their sentences who wished to stay on as free labourers in the Combine's industries. Additionally, the directive promised that prisoners who "prove[d] by consistent shock work, exemplary behaviour and habits and a conscientious attitude to the matter in hand, that they have genuinely reforged themselves" would be released before their term to remain in Karelia as 'colonisers' (kolonisty). ${ }^{46}$

By the end of 1933, the OGPU had already transferred approximately 15,000 exiled peasants to the BBK.47 By January 1936, the BBK possessed 23 labour settlements, with a total population of approximately $28,000.48$ This number declined gradually over subsequent years. ${ }^{49}$ By nationality (as of October 1938),

43. The BBK comprised in total approximately 140 outlying camps, see, for example, NA RK, f. 865 , op. 32 , d. 1/8,11.1-37, 38 .

44. This total excludes the Third Department, who were, naturally, always free security officials, BBK directive, 30 April 1935, NA RK, f. 865, op. 2, d. 4, 11. 324-330.

45. NA RK, f. 865, op. 36, d. 1, 11.35-36.

46. NA RK, f. 865, op. 1, d. 51, 11. 190-191, published in A. Iu. Zhukov et al., eds., Gulag v Karelii..., op. cit.: 91 .

47. V. N. Zemskov in V. B. Zhiromskaia, ed., Naselenie Rossii v XX veke..., op. cit.: 285.

48. Report of BBK Department of Labour Settlements (Otdelenie po trudovym poseleniiam OTP), 1936, dated February 1937, GA RF, f. 9414, op. 1a, d. 846, 1. 25.

49. For 1935 population see GA RF, f. 9414, op. 1a, d. 172, 1l. 3-5; for 1936 and 1937, ibid, d. $846,1.25$; and for 1938 , ibid., d. $960,1.4$. 
about $45 \%$ of the special settlers were Russian, $26 \%$ Ukrainian, $10 \%$ German, $10 \%$ Polish, $3 \%$ Moldavian and a mere $3 \%$ Karelian. ${ }^{50}$

Responsibility for these settlers initially fell to the BBK's Colonisation Department and its sub-divisions in the territorial Sections. In mid-1936, however, the BBK's Colonisation Department and its sub-departments were dissolved and all functions transferred to the Timber Department and its territorial lespromkhozy. ${ }^{51}$ In late 1936 the BBK sought to transfer responsibility for welfare provision in its 'special settlements' to Karelian civil administrations (in accordance with the new Constitution, which had restored certain civil rights to the exiles), although it had no intention of relinquishing control over the use of the exiles' labour. ${ }^{52}$ The BBK failed at this time, however, to divest itself of all welfare functions. Even in mid1938 , the BBK was still left with responsibility for the care of invalids and for propaganda work among the settlers. ${ }^{53}$

The strategy of colonising Karelia with freed prisoners failed because there were few incentives for prisoners to remain in voluntary exile after completing terms in the camp. A Gulag official offered his explanation in June 1935: "We train many wonderful lumberjacks but, having finished their sentences, nothing will persuade them to remain in Karelles timber stations. The conditions there are disgusting." 54 In any case, the Finnish leadership of Karelia had been unenthusiastic about the permanent settlement of politically suspect or criminal non-nationals in the autonomous border republic. ${ }^{55}$ The new Leningrad leadership of Karelia had no such reservations, but their efforts to recruit ex-prisoners were complicated by passport regulations for the border districts as well as by their failure to improve local living conditions. ${ }^{56}$

\subsection{The prisoners}

The Gulag system, like the civil economy, had its priority projects. The Belomor Canal had been prestigious and had therefore received maximum attention, but as

50. According to a report by Karelian NKVD Chief S. T. Matuzenko, 14 October 1938, to Ezhov, in Archive of the Federal Security Service of the Russian Federation in the Karelian Republic (Arkhiv Upravleniia Federal'noi Sluzhby Bezopasnosti - UFSB RF po RK), fond sekretnogo dela proizvodstva, op. 1, p. 82, d. 1938-goda, 1.84.

51. Stalinskaia trassa, 47 (8 May 1936): 2.

52. GA RF, f. 9414, op. 1a, d. 846,1. 23.

53. Report of BBK Department of Labour Colonies, 1938, GA RF, f. 9414, op. 1a, d. 1131, 1. 1.

54. Stenogram of First BBK Raikom Conference, GAOPDF RK, f. 38, op. 1, d. 1, 1. 5.

55. The first BBK data on prisoners' nationalities are for 1 October 1937 , at which time the largest groups were Russians $(68 \%)$, Ukrainians (14\%) and Belorussians $(4 \%)$. There were only 399 Karelians $(0.59 \%)$ and six Finns in the BBK, since the 1,583 Karelians and 1,129 Finns who were in the Gulag at that time were deliberately distributed outside Karelia, in particular to the Ukhtpechlag in the Komi Republic. See A. I. Kokurin, N. V. Petrov, eds, GULAG(Glavnoe Upravlenie Lagerei), 1917-1960(Moscow: Materik, 2000): 411-414.

56. Confusion prevailed in the interpretation of border zone laws and regulations, see N. Baron, "Soviet Karelia, 1920-1937," op. cit.: Chapter Five. 
soon as it was completed, large numbers of prisoners were transferred to the Moscow-Volga Canal construction (relatively few were amnestied, although this measure was given central importance in the propaganda myth of the 'redemptive' canal). ${ }^{57}$ Over the following years, the BBK's prisoner population fluctuated between about sixty and ninety thousand. One set of indicative figures (for prisoners only, excluding settlers) is given in Table 1 below.

These numbers - even after adding the labour settlers who came under BBK authority - disappointed Karelian planners, who in 1934 had projected regional demographic growth of 260,000 during the Second Five-Year Plan, of which "over half will be accounted for by the BBK." 58 The Combine's officials, too, complained of the unpredictability of the labour supply and, in particular, of its excessively rapid turnover, as prisoners arrived and were swiftly redistributed to higher priority Gulag projects. It is apparent from Table 1 that in the course of 1935, a very large number of prisoners were transferred to the BBK. This was most likely in connection with the take-over by the BBK of three lespromkhozy late in the year, and the launch of Segezhstroi and other construction projects in the autumn.

Table 1. BBK and Gulag population totals (excluding settlers), 1934-1939

\begin{tabular}{|l|c|c|c|c|}
\hline & $1 / 1 / 1934$ & $1 / 1 / 1935$ & $1 / 1 / 1936$ & $1 / 1 / 1937$ \\
\hline BBK & $70,373^{(\mathrm{a})} / 70,375^{(\mathrm{b})}$ & $66,418^{(\mathrm{a})(\mathrm{b})}$ & $90,290^{(\mathrm{a})(\mathrm{b})}$ & $58,965^{(\mathrm{a})(\mathrm{b})}$ \\
Yrly. change & - & $-5.6 \%$ & $35.9 \%$ & $-34.7 \%$ \\
\hline Gulag(b) & 510,307 & 725,483 & 839,406 & 820,881 \\
Yrly. change & - & $42.2 \%$ & $15.7 \%$ & $-2.2 \%$ \\
\hline & $1 / 10 / 1937$ & $1 / 1 / 1938$ & $1 / 10 / 1938$ & $1 / 1 / 1939$ \\
\hline BBK & $68,050^{(\mathrm{c})}$ & $79,882^{(\mathrm{b})} / 80,836^{(\mathrm{d})}$ & $79,232^{*(\mathrm{a})}$ & $86,567^{(\mathrm{a})}$ \\
Yrly. change & - & $35.5 \%$ & - & $8.4 \%$ \\
\hline Gulag(b) & $\mathrm{n} / \mathrm{d}$ & 996,367 & $\mathrm{n} / \mathrm{d}$ & $1,317,195$ \\
Yrly. change & - & $21.4 \%$ & - & $32.2 \%$ \\
\hline
\end{tabular}

* Of 1938 figure, 25,311 sentenced for counter-revolutionary crimes, and 19,304 as socially-dangerous or harmful elements(e).

Sources: (a) M. B. Smirnov, Sistema ispravitel no-trudovykh lagerei v SSSR..., op. cit.: 162; (b) V. N. Zemskov in V. B. Zhiromskaia, ed., Naselenie Rossii v XX veke..., op. cit.: 314,315 ; (c) NA RK, f. 865, op. 32, d. 1/8, 11. 1-37; (d) this figure includes 1,408 prisoners working as guards, NA RK, f. 865, op. 32, d. 1/8, 1, 38; (e) M. B. Smirnov, Sistema ispravitel' no-trudovykh lagerei $v$ SSSR..., op. cit.: 164.

57. Official published figures state that 12,484 prisoners were fully amnestied (approximately $7 \%$ of the kanaloarmeitsy), and 59,516 received reductions in sentences, in Izvestiia, 5 August 1933. The Politbiuro, however, had resolved on 15 July that the OGPU should only amnesty up to 500 prisoners, RGASPI, f. 17, op. 3, d. 926, 1. 23. It is not known whether this indicates a change of mind or deliberate deceit.

58. Karplan report to Gosplan RSFSR, April 1934, GA RF,f. A-262, op. 1,d. 1,1l. 163-178. 
In mid-1936, however, the Gulag administration in Moscow removed a large proportion of the BBK's workforce to other construction sites, such as Kaluglag (for the construction of the Moscow-Kiev highway) and to Viazemlag in Smolensk Oblast' (for the Moscow-Minsk highway). ${ }^{59}$ As a result of these transfers, while just under 39,000 prisoners arrived in the BBK in the course of the year, over 70,000 departed.$^{60}$ In Segezhstroi, labour turnover in 1936 amounted to $134 \%$ of the average annual workforce (of those who left, it should be noted, nearly half were freed) ${ }^{61}$ According to the Head of the BBK AImazov, most of the Combine's new workers only arrived in the fourth quarter, and were the "dregs" of other camps and prisons - unskilled, invalid and unable to meet norms. This, he claimed, was the primary cause of the Combine's total 1936 loss of 16,708,000 rubles (roughly the same as the projected annual profit). ${ }^{62}$

In 1937, despite hugely increasing its timber output in physical terms and fulfilling its felling target for the first time, the Combine posted a loss of over 28,488,000 rubles. To explain this failure, the BBK's new boss M. M. Timofeev, who took up his post on 28 August of that year, was keen to point out that its prisoner population, and therefore its costs, had grown far more quickly than envisaged or provided for by investment plans. Moreover, the Combine was owed over 23 million rubles, in large part by other Gulag administrations (though it was itself in debt as well). ${ }^{63}$ In late 1937, as arrests gathered pace throughout the country, the BBK experienced exceptionally rapid growth from 68,050 prisoners (excluding exiles) on 1 October 1937 to 80,836 on 1 January 1938 and 83,810 in April 1938, even during the peak of the killings carried out within the camp (see below). ${ }^{64}$

However, Timofeev reported that again a high proportion of these new arrivals were children or invalids or were registered as third category (suitable only for light work, such as sewing or leather goods manufacture), who had been transferred from other camps, in particular from Dmitlag (responsible, among other projects, for the Moscow-Volga Canal). ${ }^{65}$ It was clear, though not stated, that the repressions of 1937 had increased the total Gulag population beyond its immediate capacity to assign all inmates to productive employment. The presence in the BBK in that year of a surplus, underemployed population $(11.8 \%$ of its inmates were classed as nonworking) also undermined camp discipline and led to a sharply increased number of

59. For these sites, see M. B. Smirnov, ed., Sistema ispravitel'no-trudovykh lagerei v SSSR..., op. cit.: $280,199$.

60. Financial report of the BBK NKVD for 1936, dated 26 March 1937, GA RF, f. 9414, op. 1a, d. 844, 11. 1-6.

61. Financial report of Segezhstroi, 1936, GA RF, f. 9414, op. 1a, d. 849, 1. 92.

62. GA RF, f. 9414 , op. 1a, d. $844,1.39$.

63. Audit of BBK exploitational work in 1937, dated April 1938, GA RF, f. 9414, op. 1a, d. $953,1.140 b$.

64. These totals exclude labour settlers, whose numbers rose from 27,072 on 1 October 1937 to 28,100 in April 1938. See NA RK, f. 865, op. 32, d. 1/8, 11. 1-38 and f. 865, op. 32, d. 1/9, 1. 148. 65. GA RF, f. 9414, op. 1a, d. 953,1.14ob. 
refusals to work and escapes (see below). ${ }^{66}$ Timofeev's response in early 1938 to these problems was exceptionally harsh, as we shall see later.

\subsection{Living conditions}

Gulag living conditions, of course, reduced many of the healthy to invalids and killed the weak. Before 1937, this concerned the BBK leadership because it affected production. In December 1935, the central administration issued a reprimand to the Fourteenth Section (at Monchetundra, later, Monchegorsk), which was responsible for over 6,000 prisoners labouring on heavy construction work north of the polar circle. A central inspection had discovered an absence of baking facilities, kitchens, baths, laundries and sick rooms in many camp points. This, stated the directive, could lead to increased sickness, if not to epidemics, and, it concluded emphatically, "such administration lowers workers' morale and could lead to a fall in productivity." 67

A year later, the Deputy Procurator of the BBK Bugman carried out an inspection of the Fourth Section (located at the Vygozero lespromkhoz in central Karelia). His report detailed the following problems: there was no light or heating in the barracks, which were shared by men and women (in Maiguba camp point, six semi-naked women were found sleeping on the floor in the men's barracks); 107 teenagers were also discovered in the lespromkhoz, of whom only ten to fifteen were judged to be fit for work; there was insufficient crockery in the canteen, as a result of which the strongest prisoners who forced their way in first received all the food, while the weaker ate nothing and became too ill to work; there were too few clothes and too little bed linen (for 4,200 prisoners in the timber camp, there were 154 sheets, 233 towels, 2,445 pairs of boots and 952 hats), heightening the risk of frostbite, especially for the "southern national minorities," and leading to increased instances of prisoners refusing to work; there was no disinfecting room; there were no books, papers or radios; and the Third Department - the secret police within the camps - was judged to be arbitrary and bureaucratic in dealing with violations of camp regulations. ${ }^{68}$

\subsection{Cultural activities and 'reforging'}

These were the realities of life in the BBK, but the camp made some efforts to present itself in a different light to the outside world. In 1934, prisoners built a large hotel in Medvezh'egorsk to accommodate tourists cruising on the newly opened canal, or visiting, in the words of a 1934 report on Karelian tourism, "the animal-

66. GA RF,f. 9414, op. 1a, d. 953, 11. 10, 14, 163-165.

67. BBK directive 410, 15 December 1935, NA RK, f. 865, op. 2, d. 8, 1. 66.

68. Report dated 11-12 December 1936, GAOPDF RK, f. 38, op. 2, d. 16, 1. 2. 
breeding sovkhoz renowned in all the Union" (this was the BBK's model farm at Povenets, which employed imprisoned agronomists). Bizarrely, the Karelian tourist agency even proposed organising visits to "that area which presents such interest even in cinema films, that new town-combine organised by Soviet power on the Solovetskii islands with the aim of reforging human beings." 69 On the main Solovetskii island, the BBK had just established a prison regime for the detention of "contingents by special instruction" and this proposal came to nothing. ${ }^{70}$

In Medvezh'egorsk the BBK had its own theatre, run by prisoners, which won plaudits in 1935 for its production of The Marriage of Figaro, and for staging the first production of Evgenii Onegin in Karelia. ${ }^{71}$ In 1937 and 1938, the camp actors performed both classical operas and more modern plays with inspiring titles such as Timber and Floating. However, the theatre functioned not as a facility for the 'reeducation' of prisoners, but as a Gulag showcase for imprisoned talent: although over 45,700 tickets were sold in the 1937-1938 'season,' these were largely to civilian residents of the town, camp visitors and tourists. ${ }^{72}$ Also in Medvezh' egorsk the BBK operated a library, which claimed to stock 50,000 volumes, and to attract over 300 customers every day. ${ }^{73}$ The Combine boasted its own press, which in 1936 produced four weekly newspapers and two periodical journals. ${ }^{74}$

However, a brief glance at the BBK's relative expenditures on productive and cultural activities immediately reveals the Gulag's true priorities. In 1936, of a total expenditure within the BBK of just over twelve million rubles, only 323,000 rubles were spent on educational and cultural work (equivalent to $2.7 \%$ ). ${ }^{75}$ In the felling camps, the proportion was far lower: of 3.7 rubles spent on each prisoner daily, only 2.39 kopecks were allocated to cultural activities $(0.7 \%) .^{76}$ In 1937, the total capital investment plan for the Combine's enterprises (i.e. excluding the more important

69. Theses for 1934 report on Karelian tourism, undated, GAOPDF RK, f. 3, op. 3, d. 209, II. $26-28 \mathrm{ob}$.

70. OGPU directive 00381, 4 December 1933, cited in M. B. Smirnov, ed., Sistema ispravitel'no-trudovykh lagerei v SSSR ..., op . cit.: $396, \mathrm{fn} .4$.

71. BBK directive 148, 4 June 1935, NA RK, f. 865, op. 2, d. 2, 1. 8. For the origins of this institution in the Solovetskii camp, see Dmitry S. Likhachev, Reflections on the Russian soul (Budapest and New York: CEU Press, 2000): 127-131; N. Kuziakina, Theatre in the Solovki prison camp (Luxembourg: Harwood, [1995]).

72. BBK Raikom report, April 1937 to May 1938, GAOPDF RK, f. 38, op. 1, d. 13, 1. 145.

73. Its most popular book (especially among local komsomol members) was Ostrovskii's Kak zakalialas'stal', see Stalinskaia trassa, 13 (26 January 1936): 4. Note that No. 91, 30 September 1936, cites a total of 353,000 books in the BBK, which casts doubt on the veracity of both reports.

74. The newspapers were Perekovka, Stalinskaia trassa (the BBK party paper), Stakhanovets Segezhstroua, Iunyi stroitel', and the journals were Belomorsko-Baltiiskii Kombinat, and Pod znamenem Belomorstroiia. For details, see Stalinskaia trassa, 21 (13 February 1936).

75. It is not clear whether these figures include the BBK Youth Labour Colony at Nadvoitsy, which spent a much higher proportion of its budget on educational activities and training, see Financial report of the BBK NKVD, 1936, dated 26 March 1937, GA RF, f. 9414, op. la, d. $844,1.34$.

76. GA RF, f. 9414 , op. 1a, d. $953,1.67$. 
felling and construction activities) was 586,000 rubles (in 1936 prices), of which a mere 15,000 rubles were allocated to educational and cultural work in the factories $(2.7 \%) .{ }^{77}$ In reality, while the Combine that year spent 3.55 rubles daily on maintaining each prisoner in the enterprises, only six kopecks were expended on providing education or distraction (1.7\%). ${ }^{78}$ In the BBK's felling stations, this figure was a mere 4.87 kopecks of a total 3.65 rubles $(1.3 \%) .{ }^{79}$ In 1938 , the relative expenditure decreased further. ${ }^{80}$

Unambiguously, the BBK's priority was economic production. An order of the BBK authorities in 1935 declared that the "first duty [...] and honour" of all camp administrators was to ensure "the use of the supply of workers, at the fullest stretch and with maximum attention to achieving the most effective indicators, while at the same time [...] retaining the "full value' (pol'notsennosti) of the work force." 81 If this did not offer a sufficiently clear statement of purpose, a 1936 report by the BBK's Culture and Educational Department (Kul'turno-Vospitatel'nyi Otdel KVO) confirmed that their work was fully "determined by the task of subordinating such activity to the needs of production, in accordance with [People's Commissar of Internal Affairs G. G.] Iagoda's order No. 100-Ia of 2 April 1936 to 'decisively improve cultural-educational work, while placing it entirely at the service of production.""82 Henceforth, all cultural activities were to be directed towards improving shock work, participation in socialist competition, technical training and other means of boosting output. The Gulag no longer preached the political virtue of 'reforging' prisoners through labour; its sole 'cultural' concern, as with any economic agency, was to educate the workforce to labour more efficiently.

\subsection{Prisoner subsistence}

Such measures alone, however, could do little to motivate a weak, unskilled and recalcitrant coerced workforce. The Gulag's most potent instrument for promoting labour productivity was the distribution of food in proportion to prisoner's output. In 1935, all Gulag camps, including the BBK, adopted a new and elaborate system of distributing rations, a more sophisticated form of the incentive scheme developed by N. A. Frenkel' in the Solovetskii camp in the late 1920s (for which, see the earlier paper). There was an incremental bread ration, which for those carrying out heavy work (such as felling) ranged from 300 grams of bread per day

77. Financial-Economic report of the BBK, 1937 Enterprises, dated April 1938, GA RF, f. 9414, op. 1a, d. 952, 11. 55-56.

78. Fifty kopecks were spent on medical and sanitary provisions, 51 on clothes and one ruble 29 kopecks on food, in ibid., f. 9414 , op. 1a, d. 959, 1.72.

79. GA RF, f. 9414 , op. 1a, d. $953,1.167$.

80. BBK report for 1938, no date (early 1939), GA RF, f. 9414, op. la, d. 1125, 1.62.

81. BBK directive, 15 July 1935, NA RK, f. 865, op. 2, d. 2, 1. 92.

82. Report dated 1 September 1936, GAOPDF RK, f. 38, op. 1, d. 5, 11. 21-24. 
for fulfilling less than $25 \%$ of the daily norm to one kilogram of bread for fulfilling the target by over $125 \%$. These rations were adjusted downwards for those working in the BBK's industrial enterprises (clothes and leather manufacturing, sewing, etc.) or in lighter subsidiary activities, as well as for those undergoing punishment, and upwards for those working north of the Arctic circle ${ }^{83}$ In addition to bread and sugar, prisoners achieving their daily work norms would receive one litre of standard broth (see Table 2); those overfulfilling their norms by up to $10 \%$ in heavy or industrial work would receive 1.25 litres of the standard broth, plus an extra dish from the weaker 'premium' cauldron; those overfulfilling their norms by over $10 \%$ in heavy or industrial work would receive 1.6 litres per day of the standard broth, plus an extra dish of the 'premium' broth. Those who overfulfilled their norms would also be permitted to purchase extra vegetables and tomato puree for their 'premium' cauldron plus up to eleven grams of macaroni. Those grossly underfulfilling their norms would receive only 0.6 litre per day from the 'punishment' cauldron, with no right to purchase anything more. ${ }^{84}$ Prisoners would also receive monthly rations of soap (up to 300 grams per month), tobacco (up to 200 grams) and cigarette paper (up to four booklets), according to their productivity. Third category prisoners received the same rations, but worked to reduced output norms.

Table 2. Normative daily food rations for BBK prisoners (grams), January 1935

\begin{tabular}{|l|c|c|c|}
\hline \multicolumn{1}{|c|}{ Ingredient } & Standard & Punishment & Premium \\
\hline Flour & 10 & 10 & 25 \\
Groats & 80 & 40 & 23 \\
Meat (8 days/month) & 100 & - & - \\
Fish (22 days/month) & 175 & 70 & 35 \\
Vegetable oil & 10 & 6 & 1.2 \\
Vegetables & 500 & 400 & 220 \\
Salt & 20 & 20 & - \\
Tomato puree & 3 & 3 & 3 \\
Pepper & 1 & 0.1 & - \\
Bay leaf & 0.25 & 0.25 & - \\
\hline
\end{tabular}

Source: BBK directive, dated 7 January 1935, in NA RK, f. 865, op. 2, d. 1.5.

The Gulag's ration norms did not go unchallenged. In May 1936, the Union Procurator A. Ia. Vyshinskii declared that 300 grams of bread for punishment rations meant reducing the prisoner to starvation, and was hence contrary to the law. In a

83. BBK directive, I May 1935, NA RK, f. 865, op. 2, d. 1, 11. 205, 206.

84. BBK directive, 7 January 1935, NA RK, f. 865, op. 2, d. 1.5. 
letter to the Union Sovnarkom, he cited an investigation of the Svir' camp (not part of the BBK) on Karelia's southern border with Leningrad Oblast' (this camp was not under the BBK's authority, but was subordinated directly to Moscow) :

"In practice, Gulag NKVD norms lead to the extreme physical exhaustion of the prisoner and to the point where, as has happened, for example, in Svir lag, there are up to 5,000 weak prisoners, unable to carry out any heavy prison work because of their physical condition, and where prisoners are driven by hunger to hunt for scraps in rubbish pits." 85

Narkom Iagoda, in reply, denied that the "poor bandits in the camps" would starve if they refused to work. The law stipulated, he argued, that prisoners should be fed sufficient calories to enable them to carry out their allocated tasks. Therefore the determination of each prisoner's calorie intake should be "determined by how much labour that prisoner expends, and how much nutrition compensates for his expenditure of energy and stimulates labour productivity." The majority of camp inmates, he continued, received 800 grams of bread each day and hot food twice daily and could buy extra rations with their wages. "Why," he asked, "should a criminal who finds himself in a camp work, if even without working he can eat his fill and get whatever he wants?" In conclusion, he noted that the population of Svir'lag was not weak because of starvation, but because it comprised mainly prisoners transferred from other camps who were already infirm and unsuitable for heavy labour. ${ }^{86} \mathrm{~A}$ further Procuracy investigation of the Svir' camp found that this was not the whole truth. The prisoners were in fact in such feeble condition because, although they were indeed mostly third category as Iagoda had claimed, their labour productivity was being measured according to first category output norms, and they were receiving proportionately reduced rations. Conceding that the local Svir' administration had infringed regulations, the NKVD nevertheless issued a directive confirming the existing scale of rations, merely adding an admonishment to camp commandants that they should correctly apply productivity norms established for each prisoner category. ${ }^{87}$

Regardless of central Gulag norms, the actual rations received by BBK prisoners changed continually in subsequent years as supplies fluctuated and the camp strove with varied success to establish its own agricultural base and to secure selfsufficiency in certain foodstuffs. In general, rations of products which could not be cultivated or bred in the northern climate tended to decrease. In particular, the BBK was unable to secure sufficient grains - in 1937 a prisoner engaged in felling who

85. Letter to Molotov, 28 May 1936, GA RF, f. 5446, op. 18a, d. 850, 11. 4-5. Svir'lag indeed had one of the highest mortality rates among Gulag camps. According to Zemskov, in 1935, there were 3,887 deaths in Svir lag, in contrast to 1,362 in the Belbaltlag (only Bamlag had higher mortality). See V.N. Zemskov in V.B. Zhiromskaia, ed., Naselenie Rossii VXX veke..., op. cit.: 319 .

86. Letter to Molotov, 17 June 1936, GA RF, f. 5446, op. 18a, d. 850, 11. 14-16.

87. Letter from Vyshinskii to Molotov, 11 September 1936, GA RF, f. 5446, op. 18a, d. 850, 1. 19. 
fulfilled $100 \%$ of his norm would receive only 900 grams of bread and those engaged in lighter work would be given only 600 grams (with the right to purchase up to one kilogram at the camp shop). ${ }^{88}$ On the other hand, the relative success of the BBK's stock-breeding operations at Povonets increased meat rations above the norm. 89

Naturally, the prisoners did not always receive these rations in full. A report by the Deputy Head of the BBK's Department of General Supplies in 1937 declared that provisions, especially of fish, fats, grain and fodder (for livestock), were inadequate because of the BBK's credit problems, lack of financial discipline and swindling. As he was writing, the camp had no stock of macaroni or even of cod (although the BBK ran its own White Sea fishing and preserving enterprises). Foodstuffs, he complained, were of very low quality and had often already deteriorated below acceptable standards by the time they were delivered to the camp. ${ }^{90}$ The actual average daily consumption of the camp population in the first half of 1937 is illustrated in Table 3 - of course, the volume and quality of supplies reaching some of the more remote BBK camps would not permit the prisoners to receive even these quantities.

Table 3. Actual daily consumption of BBK camp population, 1937 (in grams, excluding guards, sick, punishment rations)

\begin{tabular}{|l|c|c|c|}
\hline \multicolumn{1}{|c|}{ Product } & Norm & Actual 1st Qu. & Actual 2nd Qu. \\
\hline Rye flour (for bread) & 600 & 536 & 553 \\
Groats & 100 & 105 & 96 \\
Meat & 27 & 40 & 42 \\
Fish & 150 & 96 & 106 \\
Vegetable oil & 10 & 7.3 & 5.3 \\
Animal fat & - & 5.6 & 2.3 \\
Macaroni & 10 & 8.6 & 1.2 \\
Vegetables & 750 & 850 & 756 \\
\hline
\end{tabular}

Source: GAOPDF RK, f. 38, op. 2, d. 16, 11, 151-154.

\subsection{Sickness and mortality}

As one would expect, in these conditions the incidence of sickness among prisoners was extremely high. Initially, the BBK benefited from a relatively strong

88. BBK directive, 31 January 1937, in ibid., op.1, d. 8, 1. 257 and BBK directive, 11 January 1937, ibid., 1. 274.

89. Kulaks exiled to the BBK's labour settlements had brought with them 954 animals, and further stock had since been purchased or bred, to maintain a cattle herd of approximately 1,600 head, GA RF, f. 9414, op. 1a, d. 762,11. 3-5 (1935) and d. 846, 1. 27 (1937).

90. GAOPDF RK, f. 38, op. 2, d. 16, 11. 151-154. 
workforce: at the end of $1934,79.8 \%$ of its 65,800 prisoners were classed as first category (fit for heavy work, against an average for all NKVD camps of $71.6 \%$ ), only $6.5 \%$ were ill or suitable only for light work (versus a Gulag average of $10 \%$ ) and only $8.8 \%$ were classed as non-working (Gulag average of $16.5 \%$ ). ${ }^{91}$ However, as we have seen, these prisoners were transferred to heavy labour projects in other camps during 1935-1936 and the new workforce which arrived in the BBK in late 1936 included a high proportion of third category prisoners.

Expenditure on healthcare was minimal. In 1936, the BBK's total capital investment on health and sanitation was only 413,000 rubles (equivalent to $3.4 \%$ of total annual capital investment). ${ }^{92}$ In the felling camps, which had a higher incidence of injury and debilitation than the industrial enterprises, average per capita budgetary expenditure was slightly higher at 24 kopecks per day (6.5\% of total daily cost per prisoner).$^{93}$ In 1937 , the BBK planned to raise expenditure to provide for the weaker incoming workforce (in 1937, $11.8 \%$ were classed as 'nonworking,' including invalids, third category and hospitalised prisoners). ${ }^{94}$ However, the Combine's actual expenditure fell steeply, because the BBK lacked trained medical personnel to deliver healthcare. ${ }^{95}$ In the BBK's enterprises, a mere 5,000 rubles (in 1936 prices) were directed to capital investment in health and sanitation (equivalent to $1.12 \%$ of total investment), instead of a planned 84,000 rubles (14\%). ${ }^{96}$ In the BBK's felling and construction camps, budgetary spending on healthcare was five million rubles ( $8 \%$ of total costs), instead of a projected seven million rubles (12\%). ${ }^{97}$ In 1938, the proportion of non-working prisoners remained steady, but actual budgetary expenditure on their healthcare nearly doubled (to $14 \%$ of total costs), partly at the cost of spending on food, which fell by $15 \% .98$

Predictably, the combination of hard labour and poor medical provision resulted in high mortality rates. Table 4 below sets out published data on mortality in the prison camps. 99

91. GA RF, f. 9414 , op. 1, d. $3455,11.4-8$. There were 720,000 prisoners in fifteen camps in December 1934, an increase from 509,400 at the beginning of the year, in ibid., 11. 2,3.

92. GA RF, f. 9414, op. 1a,d.844,1.34.

93. GA RF, f. 9414 , op. 1a, d. 953,1. 167.

94. Ibid., 11. 163-165.

95. Ibid., 1. 14. The BBK also lacked accountants, engineers and other specialists, because they had been transferred to other Gulag administrations.

96. GA RF, f. 9414, op. 1a,d.952,11. 55-56.

97. Alternative figures, however, are six million spent ( $10 \%$ of total, equivalent to 38 kopecks per person per day) against 4.2 million envisaged (7\%), GA RF, f. 9414, op. 1a, d. 953, 11. 13ob, 167.

98. GA RF, f. 9414, op. 1a,d. 1125,11.61-62.

99. The Karelian archives contain only sparse mortality statistics, which generally confirm the published figures. See, for example, data on movement of prisoners, 1 January 1938, NA RK, f. 865 , op. 32 , d. $1 / 8,1.89$. 
Table 4. Estimated total Gulag and BBK mortality, 1934-1939

\begin{tabular}{|l|c|c|c|c|c|c|}
\hline & 1934 & 1935 & 1936 & 1937 & 1938 & 1939 \\
\hline $\begin{array}{l}\text { Deaths in camps } \\
\text { Av)(b) }\end{array}$ & 26,295 & 28,328 & 20,595 & 25,376 & 90,546 & 50,502 \\
$\begin{array}{l}\text { Average Gulag } \\
\text { population }\end{array}$ & 617,895 & 782,445 & 830,144 & 908,624 & $1,156,781$ & $1,330,802$ \\
$\begin{array}{l}\text { Mortality in total Gulag } \\
\text { population }\end{array}$ & $4.26 \%$ & $3.62 \%$ & $2.48 \%$ & $2.79 \%$ & $7.83 \%$ & $3.79 \%$ \\
$\begin{array}{l}\text { Deaths in BBK } \\
\text { Total BBK population }\end{array}$ & 1,631 & 1,362 & 1,298 & 2,271 & 3,945 & 2,462 \\
$\begin{array}{l}\text { Mortality in BBK } \\
\text { population }\end{array}$ & 70,375 & 66,418 & 90,290 & 58,965 & 79,882 & 86,567 \\
\hline
\end{tabular}

Sources: (a) V. N. Zemskov, "GULAG. Istoriko-sotsiologicheskii aspekt," Sotsiologicheskie issledovaniia, 6(1991): 14-15; (b) V. N. Zemskov in V. B. Zhiromskaia, ed., Naselenie Rossii v XX veke..., op. cit.: 319; (c) see Table 1.

It is particularly notable that after the catastrophic famine year of 1933 , the death rate declined until 1936, presumably because of the general improvement in food supplies. ${ }^{100}$ It is also striking that BBK mortality in 1937 increased considerably more steeply than the total Gulag death rate (so that the BBK accounted for nearly $9 \%$ of total Gulag deaths in that year with only $6.5 \%$ of the Gulag population), presumably as a consequence of the disproportionate number of third category prisoners transferred to Karelia, mentioned above, and because of the extent of the camp repressions, which I discuss later.

\section{Discipline and punishment, 1934-1936}

In addition to its manipulation of food rations, the BBK sought to control its population by means of two institutional agencies: the Third Department and the camp judiciary. Since its inception in 1923, the Solovetskii administration had included an Information-Investigative Department responsible for surveillance, investigation and repression within the camp population. ${ }^{101}$ Nogtev's 1930 plan for the restructuring of USKON retained a department of the same name in the central administration. ${ }^{102}$ By the time a 'Statute on BBK Sections' was produced in October 1934, this agency, with sub-departments in each territorial section, had been renamed the Third Department. It was the "operative apparat of state security within camps,"

100. In 1933-1934, mortality declined steeply from $20.1 \%$ in the whole Gulag, calculated from V. N. Zemskov in V. B. Zhiromskaia, ed., Naselenie Rossï v XX veke..., op. cit.: 311, 319 (note that p. 320 he gives an alternative figure of $15.7 \%$ for 1933 Gulag mortality, and $10 \%$ in the Belbaltlag).

101. "Statute on USLON," 23 April 1924, NA RK, f. 865, op. 32, d. 1, 1. 5.

102. NA RK, f. 865 , op. 32 , d. 4. 
and its primary task was to run agents and pursue investigations among both prisoners and the free workforce. ${ }^{103}$ Its activities were governed by special directives issued jointly by the central Gulag administration and by the political police (Glavnoe Upravlenie Gosudarstvennoi Bezopasnosti NKVD - the GUGB). ${ }^{104}$ Significantly, the Head of the BBK's Third Department was subordinate only to the Head of the Gulag in Moscow (i.e. not to the head of the local camp administration). For operative matters (recruiting and running agents, investigations and executions), he reported also to the Head of the regional NKVD Administration (UNKVD).

The judiciary was initially represented within the BBK by an Itinerant Session of the Special Collegium of the Leningrad Oblast ' Court, and from October 1935, by a resident Special Collegium and Camp Court, also subordinated to the Leningrad Oblast' judiciary, which appointed its three judges. At first, Leningrad could only find two officials willing to go to Medvezh'egorsk, and the Camp Court resorted to co-opting personnel from the Third Department to its bench (possibly under pressure from the security organs). However, the Chairman of the Leningrad Court forbade this practice as soon as he learned of it, and swiftly designated and despatched a third civil judge to the BBK. The Special Collegium was extremely busy, hearing around ten cases every day, mostly prisoners who had attempted to escape. ${ }^{105}$

During 1936, a Special Collegium of the Supreme Court of the Karelian ASSR took over responsibility for administering justice within both the camp and exile settlements. ${ }^{106}$ The Court usually sentenced prisoners to periods of solitary confinement, but for serious offences it could apply capital punishment. ${ }^{107}$ In early March 1937, for example, the court sentenced three prisoners to death: one for a triple murder, and the two others for theft and assault on a camp inmate with an axe. ${ }^{108}$ A few weeks later, the court considered the case of M. G. Afinogenov, who had first been sentenced under the law of 7 August 1932 to ten years, had been convicted five times within the camp system of escape and theft and was characterised as a "systematic escaper, gambler and hooligan." Finally, having decamped from Segezhstroi he had murdered three free workers for their clothes before being surrounded and caught. He, too, was sentenced to be shot. 109

The BBK also had a Procuracy, which according to the 1930 'Statute on Corrective-Labour Camps (ITL)' had the right to oversee OGPU (later NKVD) disciplinary actions within the camp system. ${ }^{110}$ Until late 1936 , the BBK's civil

103. As confirmed by the "Temporary Statute on ITL Third Departments," issued by Ezhov as NKVD directive 00588, 14 September 1937, NA RK,f. 865, op. 35, d. 1a/2, 1. 68.

104. "Statute on BBK Sections," 13 October 1934, NA RK, f. 865, op. 32, d. 3,1.10ob.

105. District People's Courts sentenced minor civil offences within the BBK's Sections, see Camp Court report, May 1936, in GAOPDF RK, f. 38, op. 1, d. 6, 11. 124-126.

106. BBK directive, 9 January 1937, NA RK, f. 865, op. 1, d. 8, 1. 277.

107. NA RK f. 865, op. 1, d. 8,11. 155, 178, 277.

108. BBK directive, 15 March 1937, ibid., 1. 178

109. BBK directive, 3 April 1937, ibid.,1. 155.

110. Part IV of "Statute on ITL," confirmed by SNK SSSR 7 April 1930, published in A. I. Kokurin, N. V. Petrov, eds, GULAG..., op. cit.: $65-72$. 
judiciary frequently came into conflict with the Third Department over the administration of camp discipline, just as outside the camps the State Procuracy sought to subordinate the NKVD to its interpretation of legality.

Immediate responsibility for keeping order in the camps fell to the units of armed guards (Voennizirovannaia Okhrana - VOKhR). Their quality was doubtful: they comprised mainly demobilised Red Army soldiers (many of whom, according to a 1938 BBK Raikom report, were of an 'anti-soviet' orientation), and prisoners, including convicted soldiers and security officials. ${ }^{111}$ Their numbers were inadequate: in August 1936, 1,618 men (of whom 829 were prisoners) guarded 43,232 camp inmates at 114 separate locations across territory nearly a thousand kilometres north to south. ${ }^{12}$ Their living conditions and morale were miserable. At the end of 1936, for example, the free soldiers of the 155th Regiment of NKVD Forces quartered at Povenets were still living in the temporary barracks that had been erected in 1932. Conditions were, according to their commander, "disgustingly dirty and dilapidated" and "turning into a bad joke, but one which is unfortunately taking its toll on the morale of the regiment." 13

\subsection{Escapes, labour indiscipline and strikes}

The guards' main task was to prevent escapes - it was intended that the rationing system would impel the prisoners to work. There are no systematic data on the number of escapes from the BBK during the period under survey, such as have been discovered for the Gulag as a whole. ${ }^{114}$ In August 1936, VOKhR chief Nazarov reported that during June and July of that year, 424 prisoners had escaped, representing a monthly loss of $0.53 \%$ of the camp population. Disregarding probable seasonal variations, this is equivalent to an annualised loss of $6.36 \%$ (according to published data, in 1936 the Gulag as a whole lost $6.9 \%$ of its population to escapes). According to Nazarov, this number of escapes took place because the camp had failed to "reconcile its productive tasks with the correctivelabour policies of the NKVD Corrective-Labour Camps." In other words, he believed that the BBK was too soft on its prisoner population because it concentrated on production and neglected to enforce an "appropriate camp regime." 115

111. Report dated May 1938, GAOPDF RK,f. 38, op. 1, d. 13, 11. 186-188.

112. VOKhR report, 16 August 1936, GAOPDF RK, f. 38, op. 1, d. 6, 11. 268-270ob, also published in A. Iu. Zhukov et al,, eds., Gulag v Karelii..., op. cit.: 127-131.

113. Letter of Regimental Commander to Deputy Head of Belbaltlag D. V. Uspenskii, 10 October 1936, GAOPDF RK, f. 38, op. 2, d. 5, 11. 3-4.

114. V. N. Zemskov in V. B. Zhiromskaia, ed., Naselenie Rossii v XX veke..., op. cit.: 314.

115. Of these escapees, 334 had been recaptured, GAOPDF RK, f. 38, op. 1, d. 6, 11. 268-270ob, also published in A. Iu. Zhukov et al., eds., Gulag v Karelii..., op. cit.: 127-131. 
Owing to the excessively rapid influx of prisoners to the BBK during 1937 , there was a breakdown in camp discipline during that year. During the first three winter months, 285 prisoners successfully escaped. BBK Chief Almazov reacted angrily, declaring to the Second BBK Raikom Conference in April 1937 that nearly 35,000 prisoners were released from the camp each year, and "that loss is high enough [without escapes]. We cannot afford such a turnover."116 By the end of the year there had been an unprecedented 6,720 escape attempts, equivalent to nearly $10.5 \%$ of the camp population (the figure for the whole Gulag in 1937 was $6.4 \%$ )..$^{117}$

The incidence of strikes also peaked in 1937. That year, $2.5 \%$ of working time was lost in the BBK's enterprises (principally, the sewing factory at Kem'). On average 61 people refused to work each day, despite the administration's efforts to increase productivity by encouraging Stakhanovism and socialist competition and offering prizes - including pre-term release - for high performers. ${ }^{118}$ In the felling camps, over $5 \%$ of prisoners refused to work, leading to a decline in output throughout the year until the new BBK boss Timofeev imposed a special disciplinary regime during the fourth quarter (see below). ${ }^{119}$ Sometimes these refusals to work took on the character of organised action. In March 1937, two to three thousand prisoners in the Verkhne-Vygskii lespromkhoz collectively refused to work, and picketed the camp to prevent other prisoners being brought in to replace them. As a result, 165 prisoners were arrested and charged with 'counterrevolutionary sabotage' under Article 58.14 of the Criminal Code. ${ }^{120}$

Nevertheless, a report of June 1937 on the Tunguda timber station within the same lespromkhoz stated that of 445 prisoners in the camp, up to 75 men still regularly refused to work, including some of the foremen. One supervisor, a free worker, had disappeared for three days to procure vodka supplies for his brigade. In addition, the timber station's administration had falsely reported that $90 \%$ of its prisoners were third category, and had accordingly lowered their output norms by $25 \%$, when in fact only $50 \%$ were unfit for heavy labour. ${ }^{121}$ This time the central BBK administration established a commission to investigate the causes of the breakdown in discipline, to reorganise working practices, and to bring the culprits to full account.

The problem of indiscipline was aggravated when prisoners were situated near civilian settlements. In 1935, it was reported that prisoners were stealing from local residents and selling the goods in other villages. Some were giving their prison

116. GAOPDF RK, f. 38, op. 1, d. 10, 11. 14-18.

117. All but 840 were recaptured, see Timofeev's report on BBK, 26 February 1939, NA RK, f. 865, op. 36, d. 14, 11. 1-10, also reproduced in A. Iu. Zhukov et al., eds., Gulag v Karelii..., op. cit.: $159-164$.

118. GA RF, f. 9414, op. 1a, d. 959,1.72 and ibid., d. 952,1. 14.

119. GA RF, f. 9414, op. 1a, d. 953,11.8-9, 14.

120. BBK directive, 8 March 1937, NA RK, f. 865, op. 1, d. 8,1.208.

121. BBK directive, 23 June 1937, NA RK, f. 865, op. 32, d. 6, 1. 708. 
clothes to the destitute Karelian peasantry in exchange for vodka. ${ }^{122}$ In mater of the Pindush camp near Medvezh'egorsk, who were building ship wharves, frequently wandered off the construction site into the local town during working hours, where their drinking and brawling caused concern to both camp officials and the town's inhabitants. ${ }^{123}$ Prisoners employed in the BBK administration in Medvezh'egorsk often violated their curfew (they were permitted free movement within the town between 09.00 and 23.00); some even took up residence in private apartments. ${ }^{124}$ In April 1937 (by which time the curfew had been changed to 19.00), ${ }^{125}$ a sweep of Medvezh'egorsk by the Third Department picked up no fewer than 83 prisoners without permits in the market, station, theatre, bathhouse and in shops and restaurants - most were drunk and over 15 litres of vodka were confiscated. At the same time, three Supply Department employees, all prisoners, were arrested in a Kareltorg shop in possession of 7,200 rubles. Many more prisoners were found living outside the local camp compounds. Administrators were duly reprimanded and prisoners lost their 'day credits' for drunkenness, contact with the local population and 'idling' (prazdnoshatanie). ${ }^{126}$ On the same day, 13 prisoners working at the camp theatre lost day credits for "drunkenness, debauchery, fraternisation with free citizens, appearing drunk for rehearsals, cohabitation with female prisoners" and other misdemeanours. ${ }^{127}$

\subsection{Quis custodiet custodes?}

The BBK authorities were also concerned about corruption and criminality among the NKVD apparat, at least to the extent that it undermined prisoner discipline and disrupted production. Common minor offences, which earned reprimands, fines or confinement for a few days, included drunkenness, mistreatment or molestation of prisoners, false accounting and misappropriating workers.

For more serious offences, camp officials could occasionally receive severe punishment. In mid-1935, the Deputy Head and the Chief of the Colonisation Department of the Third (Vodorazdel'noe) Section were sentenced by a Military Tribunal (responsible for hearing criminal cases involving NKVD officials) respectively to two and two and half years' hard labour for drunkenness, "abusing their official positions in order to womanise" and complicity in the escape of a labour settler after the theft of 31,000 rubles. At the same time, the boss of one of

122. Resolutions of the First BBK Party Conference, 21-23 June 1935. GAOPDF RK, f. 38, op. 1, d. 1, 1. p. 36. In the 1933 famine year, Karelian peasant women had prostituted themselves with Belomorskoi prisoners in exchange for bread.

123. BBK directive, 12 December 1935, NA RK, f. 865, op. 2, d. 8, 1. 63.

124. BBK directive, 30 October 1935, NA RK, f. 865, op. 2, d. 6, 1. 7.

125. BBK directive, 24 April 1937, NA RK, f. 865, op. 1, d. 8,1. 101.

126. BBK directive, 4 May 1937, NA RK, f. 865, op. 1, d. 8, 11. 76-77.

127. BBK directive, 4 May 1937, NA RK, f. 865, op. 1, d. 10, 1. 30. 
the sewing factories in Kem' that employed most of the female prisoners was arraigned before the Military Tribunal for mistreating inmates and compelling female prisoners to 'cohabit.' The directive publicising these measures declared that BBK workers must be "models of discipline and order."'28 The deterrent was ineffective: only one month later, another official appeared before the Military Tribunal charged with drunkenness at work and attempting to rape a female subordinate. ${ }^{129}$

BBK officials who were party members were subject to party discipline, and were frequently reprimanded, and occasionally demoted or expelled, by their party committees for offences which were considered to have a political significance. In 1936, for example, the commandant of a labour colony was reprimanded by his PPO for hooliganism. Accompanied by a guard, he had drunkenly forced his way into the office of a female exile, and decorated her room by hanging inflated contraceptives (with faces drawn on them) from the ceiling. Even though he had done this, reportedly, in celebration of the Day of the Paris Commune, his punishment was revised by a second PPO session to expulsion from the party on grounds of 'political hooliganism,' since he had lied to the first meeting. ${ }^{130}$

Regional party authorities were in this way able to intervene in aspects of Gulag life which fell under the purview of party discipline. In particular, in the course of the 1935 proverka and the 1936 exchange (obmen) of party documents, all decisions made by the BBK's party organisations to expel or demote Chekist party members were subject to review first by the Karelian Obkom and then by the Leningrad Obkom. After these higher party bodies had confirmed or revoked all exclusions and dealt with all appeals for both procedures, a total of 75 BBK party members had been expelled (approximately a tenth of all BBK party members and candidates). ${ }^{131}$ Of those excluded, 16 had been accused of having incriminating ties with prisoners, and others for facilitating escapes, for former allegiance to Trotsky, for inattentive care of weapons, and for having a 'liberal' attitude to party disciplinary measures. ${ }^{132}$ This demonstrated, declared BBK Raikom secretary Romanov at the Tenth Karelian Obkom Plenum of March 1937, that Leningrad was sending its worst and most compromised cadres to the BBK.133

The regional party bodies could also, in principle, overturn regular disciplinary decisions made by the BBK party organisation, although there is only one indication of their having done so. In October 1936, three months after the TsK had

128. BBK directive, 2 July 1935, NA RK, f. 865, op. 2, d. 2, 1. 65.

129. Report, 5 August 1935, NA RK, f. 865, op. 2, d. 5, 1. 143.

130. It is not indicated whose faces he drew. See protocol of Second BBK Section and Second VOKhR Division PPO committee, 14 June 1936. GAOPDF RK, f. 38, op. 1, d. 7, 1l. 21-23.

131. BBK Raikom report, September 1936 to April 1937, GAOPDF RK, f. 38, op. 1, d. 10, 1.52 .

132. Protocols of First BBK Raikom conference, 4 September 1936, GAOPDF RK, f. 38, op. 1, d. 1, 11. 74-77.

133. Stenogram, RGASPI, f. 17, op. 21, d. 1935, 11. 22-23. 
finally established a BBK Raikom, the Karelian Obkom bureau approved a resolution 'On manifestations of sickness within the BBK Raikom,' revoking a censure given to a party member for criticism of his party superiors in the camp. ${ }^{134}$

The BBK party authorities generally adopted a lenient attitude towards officials when camp inmates raised allegations against them. In May 1936, for example, prisoners accused an NKVD official of drunkenness, 'co-habiting' with female prisoners and coercing into sexual relations free women who had travelled to visit relatives in the camp. The official's PPO initially reprimanded him and placed him in detention for fifteen days. However, the BBK Raikom decided that the prisoners were slandering the official, repealed the sentence, directed the BBK Third Department to charge his accusers with provocation and ordered, on party authority, the Camp Procurator and the Chair of the Special Collegium to hold a special show trial of the prisoners. ${ }^{135}$

The conduct of prisoners and officials, of course, was a central issue in relations between the BBK and the Karelian civil authorities. In Soroka, where the Belomor Canal opens into the White Sea, a conflict developed in mid-1936 when two naval vessels of the Northern Fleet docked in the port and their drunken crews rioted in the town. A subsequent investigation by the Soroka militia and the Special Department of the Murmansk Okrug NKVD (investigating the sailors' role) discovered that the flotilla commander had advised the BBK Sixth (Soroka) Section of his imminent arrival and requested provisioning, but had failed to inform either the local soviet or party authorities. Hospitably, the local BBK chief Tudar had invited the officers and sailors to an evening of "drinking and festivities" at the camp headquarters. At two o'clock in the morning the revelry ended and the sailors made their disorderly way back to the ships through the town. The local militia and soviet officials were incensed at this course of events: not because they had been kept in ignorance of the flotilla's arrival, they fulminated, nor even because foreign ships in the port had been "very curious" about the sailors' behaviour, but because prisoners had known about the incoming naval detachment and had been present at the carousal. The report demanded that Tudar be dismissed for "irresponsibility and incompetence." 136 The BBK administration, however, took no disciplinary action against him; to the contrary, in the next few months he was appointed to be Chief of the Belomor Canal Administration, based in Povenets. ${ }^{137}$

Later that year, in response to a protest by the Karelian Obkom and the Karelian UNKVD concerning a crime wave in Soroka caused by roving prisoners, the BBK did undertake to tighten the camp permit regime and to ensure that prisoners could

134. Protocol 55 of Karelian Obkom bureau, 16 October 1936, RGASPI, f. 17, op. 21, d. 1965, 1.118.

135. Protocol of BBK Raikom, 20 May 1936, GAOPDF RK, f. 38, op. 1, d. 6, 1. 119.

136. Letter of Soroka Raikom Secretary, 25 July 1936, GAOPDF RK, f. 28, op. 1, d. 354, 11. 55-59.

137. See GAOPDF RK, f. 544, op. 1, d. 2, 11. 58-58ob, cited in A. Iu. Zhukov et al., eds., Gulag v Karelii...,op. cit.: 144. In 1939 he was Head of the Eighth Monchegorsk Section of the BBK, see ibid: $171-172$. 
not freely enter the town or factory. ${ }^{138}$ Such promises, however, did little to assuage fears that the free population would be 'contaminated' by the prisoners. In May 1937, the VOKhR commander, who already had to struggle with the poor morale of his guards, declared that because of poor supplies in remote settlements, soldiers and local civilians had to share food queues with prisoners, and "we all know what sort of conversations they have in those queues." 139

\section{Production and terror, $1937-1938$}

On 26 September 1936, Chair of the TsK Commission of Party Control (Komissiia Partiinogo Kontrolia - KPK) N. I. Ezhov replaced Iagoda as People's Commissar of Internal Affairs. This marked a signal change in the NKVD's status and functions. Whereas Iagoda had striven to maximise the agency's institutional and territorial authority and autonomy, his successor aimed to fuse the security organs and the communist party into a lethal instrument of power, and re-oriented the Gulag towards two core tasks: fulfilling basic productive activities and repression.

The BBK's party organisation and its officials now played a more active role in camp life, overseeing the fulfilment of economic plans, promoting Stakhanovism and socialist competition, and carrying out political propaganda work among labour settlers. In April 1937, the BBK Raikom closed down the camp administration's newspaper Perekovka ('Reforging'), an action of obvious symbolic import, and increased the circulation of its own publication Stalinskaia trassa to 7,000.140 Later in the year, Gulag political departments received a directive "to strengthen party leadership of NKVD camps and construction administrations."141 Party discipline of NKVD officials was now used as a milder alternative to Military Tribunal hearings or Third Department procedures. In October 1936, for example, the boss of a Kem camp point was accused of drunkenness and forcing female prisoners into sexual relationships (it is not known whether this was the same man as had been charged the previous year). Instead of being hauled before the Military Tribunal, however, he received an administrative reprimand, five days' confinement and was expelled from the party. ${ }^{142}$ The following month, Solovetskii prisoners reported that the Head of the Section's Third Department had entered their barracks drunk, smashed their stove and electric lights with a bottle, and then seized a male prisoner and "tried to use him as a woman." The official admitted his drunkenness, pleading in mitigation that he suffered severe depression, but denied attempted rape. Other camp officials defended him against the prisoners' allegations, and the only action taken was to transfer him

138. Karelian UNKVD report, 22 November 1936, GAOPDF RK, f. 3, op. 2, d. 17, 1. 12, and BBK Raikom Secretary letter to Karelian Obkom, 24 December 1936, in ibid., 11. 10-11.

139. Thirteenth Karelian Obkom conference, May 1937, RGASPI, f. 17, op. 21, d. 1914, 1. 235. 140. BBK Raikom bureau, 10 April 1937, GAOPDF RK, f. 38, op. 1, d. 6,1.239.

141. NKVD directive 00690,22 October 1937, NA RK, f. 865, op. 35, d. 1a/2, 1.92.

142. BBK Raikom bureau, 17 October 1936, GAOPDF RK, f. 38, op. 1, d. 5, 1. 64. 
off the island on grounds of his mental state and to dismiss him from his party organisation. ${ }^{143}$

In late 1936, the BBK Third Department in concert with the party organisation launched a campaign to discredit the camp judiciary. On 31 October, a Third Department official denounced three members of the BBK Special Collegium of the Supreme Court of the Karelian ASSR for public drunkenness in Medvezh'egorsk. The next day, the Court and Procuracy PPO reprimanded the miscreant judges. A few weeks later, the Karelian Supreme Court removed the offenders from their posts. Not content with this resolution of the affair, however, the BBK Raikom bureau soon afterwards expelled all three from the party for compromising their authority in front of prisoners, and disciplined three other court and procuracy officials for failing to prevent the violation. For good measure, they requested the Karelian Obkom to direct the Karelian People's Commissariat of Justice (Narkomiust) to dismiss the Chair of the BBK Special Collegium as well. ${ }^{144}$

In December 1936, the BBK Procurator Epishin launched a counter-attack, delivering to the BBK Raikom bureau a report on the Third Department's Investigative-Isolation Block (Sledstvennyi Izoliator - SIZO) in Medvezh'egorsk. Security officials, it turned out, were detaining a large number of local residents whom they had mistakenly arrested as escaped prisoners. Indeed, the Third Department's record-keeping was so bad - it had registered only half of the 20,000 prisoners who had arrived during October and November - that it had no way of identifying who were prisoners and who were free citizens. ${ }^{145}$

At the Second BBK Raikom Party Conference in April 1937, a judicial representative complained that "the Court and Procuracy are treated everywhere with disrespect - and your disrespect for us makes our work much harder. We cannot assert our authority, and the blame for this must be shared by the party committee." 146 Epishin agreed that the Third Department was particularly guilty of undermining their work. A security official retorted with criticism of the judiciary's handling of escape cases, stating they should hold show trials instead of transferring individuals to his agency for secret punishment. Next, a Karelian Obkom representative aligned himself with the BBK Third Department by sternly condemning the Camp Court's loss of vigilance. Ominously, he informed the NKVD party members that the regional committee was already debating the failings of the republican judiciary (we learn from other sources that a week earlier the Deputy Karelian Procurator had committed suicide because he believed

143. Closed Section of Solovetskii Camp Point Party Committee, 10 November 1936, GAOPDF RK, f. 38, op. 1, d. 5, 11. 112-13. Service on Solovetskii Island took its toll on officials, even though they received a $40 \%$ salary bonus. In July 1937, the new Head of the Third Department on Solovki was dismissed for drinking a litre of vodka (although alcohol was, in fact, banned on the island, GAOPDF, f. 38, op. 1, d. 7, 1. 149) and dancing around the camp with a guitar, see ibid., op. 2, d. 16, 1.189.

144. GAOPDF RK, f. 38, op. 1,d. 5,11. 164-165, 149-151.

145. GOAPDF RK, f. 38, op. 2, d. 16, 11.42-43.

146. Stenogram, 24-28 April 1947, GAOPDF RK, f. 38, op. 1, d. 10, 1. 2. 
"someone was trying to frame him"). 147 A conference resolution castigated the Court and Procuracy for the drunkenness of five of its members and the "political errors" of three others, for abuse of official positions (referring to the incident of October 1936), and an absence of self-criticism and vigilance.

The same month, the Karelian Obkom ordered the republican Narkomiust to dismiss the Chair of the BBK Court, A. G. Bogdanov, for "political errors." In May, Bogdanov appeared before the BBK Raikom bureau, where he was accused of rightist activity while a People's Judge in Leningrad Oblast', having displayed a 'liberal' attitude to kulaks during collectivisation. Furthermore, since arriving in the BBK he had acquitted a certain Moglin, purportedly a son-in-law of Trotsky, of charges of counter-revolutionary activity (although the Procurator had returned the case for review and Moglin was then sentenced to a further five-year term). ${ }^{148}$ Bogdanov was issued with a reprimand and excluded from all judicial work, and the BBK Raikom requested that the Karelian Obkom expel him from the party.

In early 1937, the NKVD took further measures to prepare for the launch of repressions within the camp. In February, the Solovetskii Section was transferred out of BBK authority to the Tenth Department of the GUGB NKVD in Moscow to use as a high-security prison. ${ }^{149}$ As the BBK's Third Department reported directly to the central administration of the political police, and on "operative" matters to the Leningrad and Karelian branches, this strengthened the camp security agency's autonomy from interference by local officials preoccupied with production. In practice, Leningrad UNKVD boss L. M. Zakovskii controlled the Solovetskii prison and through his 'client' Karelian NKVD chief K. Ia. Tenison also appointed key Third Department officials in the BBK's mainland administrations. Also in the first half of 1937, all prisoners sentenced for counter-revolution were removed from the camp administration. In July, the BBK's KVO warned of increasing counter-revolutionary activity and agitation among criminal inmates and labour exiles: there was "ideal soil for fascist, trotskyite, counter-revolutionary elements to use these prisoners against the corrective-labour policy of the Soviet state."150 The KVO proposed to counter this threat by improving educational work; the Third Department had different plans.

147. Karelian Procurator's report, 19 April 1937, GAOPDF RK, f. 16, op. 3, d. 64, 11. 25-30. A little earlier the Procurator of Leningrad Oblast' had also committed suicide.

148. BBK Raikom bureau, 22 May 1937, GAOPDF RK, f. 38, op. 1, d. 11, 11.23-24.

149. NKVD directive 76, 20 February 1937, NA RK, f. 865 , op. 35, d. la/2,1.3. On 14 August 1937, the Sovnarkom SSSR agreed to a request by Ezhov to raise salaries on Solovki, in view of the especially hard working conditions and high minimum subsistence level, see GA RF, f. 5446, op. 20a, d. 944, 11.123-125.

150. KVO report to July 1937, undated, GAOPDF RK, f. 38, op. 1, d. 9, 11. 18-26. 


\subsection{Mass killing in the BBK}

On 30 July 1937, Narkom Ezhov issued NKVD Directive 00447, which established regional quotas for mass repressions. On 5 August, he sent a coded telegram to Zakovskii, Tenison, Temporary Acting Head of the BBK M. M. Chuntonov and Head of the BBK Third Department Astrov, ordering the execution under Directive 00447 of 800 of the "the most active anti-soviet elements among former kulaks, execution squads (karatelei), bandits, whites, sectist activists, clergy and other counter-revolutionaries conducting active anti-soviet disruption in the camps."151

The Karelian NKVD troika (comprising Tenison, Karelian Obkom First Secretary M. N. Nikol'skii and Karelian Procurator G. S. Mikhailovich) held its first session on 17 August, and sentenced to death 110 prisoners on the basis of files submitted by Head of the Secret-Political Group of the BBK Third Department P. P. Dolinksii. ${ }^{152}$ The executions commenced on a small island in a central Karelian lake on 22 August. ${ }^{153}$ Recently published figures, drawn from the records of the Karelian troika reveal that the full quota of 800 victims had already been shot by 21 September (see Table 5). The troika - the membership of which changed as its officials were themselves removed and shot - nevertheless continued to hear BBK cases at intervals until 10 November 1938, a year after the operation was scheduled to end. The final number of executions was 2,543 , exceeding the designated quota threefold. ${ }^{154}$

Table 5. Karelian ASSR NKVD Troika sessions "on the BBK line"

\begin{tabular}{|lc|lc|}
\hline Date & Sentenced to death & Date & Sentenced to death \\
\hline 1937 & 110 & 1938 & \\
17 August & 152 & 17 January & 59 \\
26 August & 143 & 21 January & 80 \\
2 September & 160 & 31 July & 42 \\
9 September & 270 & September 1 & 96 \\
20 September & 399 & 10 November & 146 \\
20 November & 412 & Total 1938 & $264^{*}$ \\
18 December & 210 & & $687^{*}$ \\
29 December & 1,856 & TOTAL 1937+1938 & $2,543 *$ \\
Total 1937 & \multicolumn{2}{l}{} \\
\hline *Plus 192 cases transferred to the BBK Court
\end{tabular}

Source: I. Chukhin, Karelia-37, op. cit.: 146-147.

151. Ivan Chukhin, Kareliia-37. Ideologiia i praktika terrora (Petrozavodsk: Izd. Petrozavodskogo Gosudarstvennogo Universiteta, 1999): 160.

152. Ibid: 123

153. Ibid.: 124 .

154. But note that data collated from Karelian NKVD periodical reports to the Eighth Department of the GUGB NKVD in Moscow indicate 59 fewer executions under Directive 00447 between 5 August 1937 and 25 January 1938, and an additional 187 executions between 25 January and mid-April, plus an unspecified number under Directives 00485 (Poles) and 00593 (Kharbin Russians), Arkhiv UFSB po RK, Fond Ugolovnykh del na lits, sniatikh separativnogo ucheta, d. 168, Vol. 1,11.41, 104-110, 114. 
Recently published documents give us an insight into the procedures used by Third Department officials to collect materials on inmates. Former tsarist officer, right socialist revolutionary then communist party member and Administrator to the Ukrainian Sovnarkom Petr Kirillovich Solodub had been sentenced on 5 September 1933 to ten years for membership of the counter-revolutionary Ukrainian Military Organisation (UVO). He was transferred to the Solovetskii camp (USLAG) the same month, where the Special Department began to monitor him under surveillance case "Aktivnye" and ordered that he should be kept in isolation. At the end of the year, after the camp's transfer to BBK jurisdiction, the Special Group of the Third Department of the Solovetskii Section drew up a profile of the prisoner which stated that he was "behaving peacefully" waiting to be restored to normal living conditions. ${ }^{155}$ Solodub remained, however, in isolation until the following spring, when he was given work in the Solovetskii Finance Department. In April 1934, he wrote a long appeal to the OGPU Collegium relating in detail his rejection of "Shumskyite national-fascism" and declaring that "there is no order that I would not fulfil and no action that I would not take in the name of the party and revolution." 156 Informers reported that he sincerely believed his case would be reconsidered and he would be freed, but the BBK Third Department continued to characterise him as the "most odious figure" of the thirty-five people in the camp convicted of UVO membership. ${ }^{157}$ The Third Department instructed its informers

"to continue to study prisoner Solodub's mood and establish in conversation
with him, who [else] is interested in Shumskii [...] As prisoners Geodenov and
Benidik are active counter-revolutionaries in Solovki, record all their most
trivial comments about Solodub and conversations with him, establishing what
the latter is most interested in and how they use these conversations."158

During 1935, the Third Department continued to monitor Solodub. However, according to the Head of the Third Department of the Section Akimov and chief investigator Dolinskii,

\begin{abstract}
"Because prisoner SOLODUB lives in complete isolation in the camp (in a separate room outside the Kremlin camp point) and does not work - the use of agents to collect information is extremely difficult, for which reason we held insufficient agent materials on his case until recently. In January we recruited special informants (spetsial'nye osvedomiteli) 'Iasinskii' and 'Chermash' to collect information on SOLODUB [...]"
\end{abstract}

On the basis of these agents' reports and from reading the prisoner's letters, the NKVD officials concluded that although Solodub continued to declare his loyalty

155. Documents reproduced in Ivan Drach et al., Ostannia adresa. Do 60-richchia solovets'koi tragedii, Vol. 2 (Kiev: Sfera, 1998): 102.

156. Ibid.: pp. 102-125, 125.

157. Ibid.: 125 .

158. Ibid: 127. 
to the Soviet regime, his declarations were "insincere." They continued to watch him as during 1936 he became increasingly dissatisfied with his confinement in the Solovetskii Kremlin. In May, he threatened to stage a hunger-strike. ${ }^{159}$ In the same month, an agent reported that Solodub sincerely believed in Stalin, but intensely hated Chekists, whom he believed were a "negative factor in the revolution," an opinion unlikely to endear him to his captors. ${ }^{160}$ In October 1937, a new report on Solodub stated definitively that he was a

"convinced enemy of Soviet power. Maliciously oriented. Sharply criticises policies of VKP(b) and Soviet government, especially national policy in Ukraine [...]. Since arriving on Solovki, Solodub has gathered round him likeminded thinkers, UVO and Ukrainian National Counter-Revolutionary Organisation (UNKR) members, Polish spies, among whom he enjoys high authority $[\ldots] " 161$

On the basis of this report, Solodub's case was sent to the troika of the Leningrad Oblast' UNKVD (comprising Zakovskii, his deputy V. Garin and Leningrad Procurator B. Pozern) and on 9 October he was sentenced to death. The Leningrad troika was responsible for processing cases from the GUGB prison on Solovetskii Island, since it was now separate from the BBK. On 9 October, as well as Solodub, it sentenced another 656 Solovki prisoners to death, the following day another 249 and on 14 October another 210 . The 1,116 prisoners were shipped to the mainland at Kem', then taken by railway to Medvezh'egorsk where they were held in the BBK Third Department's SIZO (which was built to accommodate only 300 inmates). Then, on 27 October and each day from 1 until 4 November, contingents of prisoners were taken sixteen kilometres by lorry along the Povenets road to a point near the village of Sandormokh, "the usual place for carrying out sentences on Belbaltlag prisoners," according to the later testimony of one of the NKVD participants. Beside the road, in a sand and gravel pit where digging was easy, they were executed with a revolver shot to the back of the head. Captain M. Matveev of the Leningrad UNKVD personally carried out a majority of the executions, between 200-250 per day. ${ }^{162}$ The corpses were then thrown into shallow pits, which already contained hundreds of victims of Directive 00447 and other mass operations, both on the Karelian and BBK 'lines.' Sandormokh continued to be used as an execution site during the following year. Excavations of the mass graves in 1997 revealed between 5,000 to 6,000 corpses. 163

159. Ibid:: 130 .

160. Ibid:: 131 .

161. Ibid.

162. The number actually executed was 1,111 , since a few prisoners had died during the transfer and in the SIZO. Beniamin Ioffe, "Solovetskii rasstrel 1937 goda," in I. Drach et al., Ostannia adresa. Do 60-richchia solovets koi tragedii, Vol. 1 (Kiev: Sfera, 1997): 28-30.

163. Times (5 July 1997): 14; Catherine Merridale, Night of stone. Death and memory in Russia (London: Granta, 2000): "Introduction." 
On 10 and 25 November 1937, the Leningrad Oblast' UNKVD troika signed another three protocols, in total consisting of 509 Solovetskii prisoners, who were transported to Leningrad for execution in December. On 14 February 1938, the troika signed one final protocol with the names of a further 200 prisoners who, because navigation to the mainland was now closed, were shot on the island itself..$^{164}$

\subsection{Economic aspects of the repressions}

The NKVD's economic role grew as arrests in the country at large intensified. In September 1937, the Union Sovnarkom decreed that vast forest territories were to be transferred to Gulag operations in nine areas of the Soviet North (the list did not include Karelia). ${ }^{165}$ The Gulag established seven new camps in these regions with a workforce of over 100,000. In December 1937, the Sovnarkom's Economic Council (Ekonsoviet) transferred yet more timber areas to the NKVD in Vologda, Kirov, Sverdlov and Krasnoiarsk regions. ${ }^{166}$ In June 1938, the Soviet government transferred a large number of indebted Narkomles enterprises to the NKVD, including several in Karelia which came under BBK control. ${ }^{167}$ The NKVD was able to take on these additional tasks since it now had at its disposal a vast and rapidly growing workforce. During 1937 , nearly 636,749 new prisoners arrived in the Gulag (a 47\% increase over 1936). During 1938, a further 803,007 new prisoners arrived, bringing the total Soviet camp population to over one million for the first time, despite the extremely high death rates. ${ }^{168}$ Within the BBK, too, as we have seen, there was extremely rapid population growth in 1937 and early 1938, even during the peak of the killings within the camp.

These figures suggest that it was the growth in labour supply resulting from the mass arrests, outstripping the murderous capacities of the GUGB and Third Departments, that drove the NKVD to expand the economic role of its camp system. Conversely, of course, this expansion of its economic operations meant that the NKVD needed to assure itself of a continuing supply of labour if it was successfully to fulfil its tasks while still carrying out its repressive functions. After all, in both 1936 and 1937 just over $44 \%$ of the Gulag population was annually released, the highest proportions since the start of the decade. It is quite likely, therefore, that such a motive fuelled the accelerating dynamic of arrests in late $1937 .{ }^{169}$ It is improbable, however,

164. B. Ioffe, "Solovetskii rasstrel," ... art. cit.: 28.

165. Resolution of 23 September 1937, GA RF, f. 5446, op. 22a, d. 139, 11. 23-29, 31-32.

166. GA RF, f. 5446 , op. 20 a, d. $56,1.3$.

167. Letter of Deputy NKVD V. V. Chernyshev, 27 February 1939, GA RF, f. 5446, op. 23a, d. 117, 11.24-25.

168. V. N. Zemskov in V. B. Zhiromskaia, ed., Naselenie Rossii v XX veke..., op. cit.: 314.

169. On economic sources of the terror, see S. Swianiewicz, Forced labour and economic development. An enquiry into the experience of Soviet industrialisation (London: OUP, 1965): 133-136. 
that the repressions were deliberately launched to increase the Gulag's workforce or institutional authority. On the contrary, the camps were manifestly caught unprepared by the massive new influx of prisoners from mid-1937, as the evidence of inadequate funding, plan failures, underemployment and rising numbers of strikes and escapes in the BBK cited above demonstrates.

Under Timofeev's leadership, the BBK from August 1937 no longer concerned itself with visionary industrial planning, but focussed all its efforts on fulfilling the felling plan. Timofeev's priority was to strengthen discipline among both prisoners and free administrators. In September, he reprimanded the Timber Department for spending over its budgeted limits, stating that "it is necessary once and for all to put an end to this criminal attitude to the unquestionable precondition of a socialist economy, that all capital investment must be made in exact accordance with the agreed plans and estimates." Such infractions were no longer subject merely to party discipline: Timofeev directed the Third Department to investigate the administration and punish those responsible. ${ }^{170}$

Timofeev was also determined to extract maximum output from the prisoners. As we saw above, during the first half of 1937 discipline had disintegrated (with escapes exceeding $10 \%$ of the camp's population). As a result, the BBK posted an overall loss for 1937 of more than 28 million rubles. Determined to break even in the following year, Timofeev took measures to establish discipline in the camp. As a first step, he ordered in late 1937 that prisoners working as camp guards should be replaced by free soldiers and that the total number of guards should be increased as part of a stricter camp 'regime.' 171 This directive does not seem to have been implemented immediately, however, since on 1 January $193837 \%$ of the BBK guards were still prisoners. ${ }^{172}$ Nevertheless, by the end of 1937 spending on the guards' maintenance and payment exceeded planned costs by $34 \%$ (representing over $15 \%$ of all budgetary expenditure). ${ }^{173}$

Then, on 8 January 1938 Timofeev issued a special directive ordering 25 prisoners to be shot for attempted escape. The directive was accompanied by a special document addressed to all BBK Heads of Sub-Divisions, which makes clear the deterrent aim of these killings:

"Study the attached directive with great care in all sub-divisions, and immediately bring it to the attention of the entire camp population. Explain the meaning and purpose of the measures taken: a merciless campaign against escapes, there must be no more escapes. After publicising these explanations, inform me of the results in terms of the mood of the camp masses, especially among the negative element." 174

170. BBK directive, 22 September 1937, GAOPDF RK, f. 38, op. 2, d. 16, 1.239.

171. Report on BBK exploitational work for 1937, April 1938, GA RF, f. 9414, op. 1a, d. 953, 1. $13 \mathrm{ob}$..

172. "Distribution of BBK Sections," NA RK, f. 865, op. 32, d. 1/8, 1. 38.

173. GA RF, f. 9414 , op. 1a, d. 953,1.13ob.

174. Cited in V. Semkin, “Belbaltlag: prikazi 1938," Leningradskaia pravda (5 April 1990): 3. 
Over the following months, the Third Department intensified the number of arrests and carried out further shootings at regular intervals. On 1 January 1938, the SIZO of the Fourth (Segezha) Section, where 7,019 prisoners (6,846 men and 173 women) were employed building the paper-pulp combine, contained 57 inmates. Four months later, on 1 April, the Section employed 8,488 prisoners and the cells contained 377 inmates, an increase of over fivefold (without, we assume, any increase in the holding capacity of the block). ${ }^{175}$ It is unlikely that Timofeev's victims had actually attempted to escape during this period, since they seem to have been selected in batches straight from the Third Department's files: the execution lists reveal that they were shot in alphabetical groups (on 18 January, seven prisoners were shot with surnames beginning with ' $g$,' another seven with 'd' and 27 with ' $k$,' and so on). ${ }^{176}$ In January, a total of 289 prisoner were shot under the 8 January directive. On 23 February, Timofeev rewarded Third Department officials for "having enabled the 1937 felling plan to be successfully fulfilled." In May, Timofeev noted a slowing down in the number of executions, and warned that the original directive was not being "sufficiently publicised" among the camp population. In the following month, the Third Department trebled the number of executions. In July, having already shot nearly 700 prisoners for attempted escape, Timofeev boasted that the first quarterly timber plan had been fulfilled by $107 \%$. Nevertheless, the Third Department continued shooting prisoners throughout the late summer and autumn. Adding the final toll of 1,001 victims of the 8 January order to those shot under the NKVD mass operations cited above, the total number of prisoners executed by late 1938 amounted to 4,655 (published data indicate BBK mortality for 1937-1938 totalled 6,216). ${ }^{177}$

There seems to have been at least one unforeseen effect of Timofeev's policy in the winter of 1937-1938. The VOKhR divisions had always been a problem, but now the guards' morale finally collapsed. At the BBK Raikom Party Conference of May 1938, it was reported that during the previous months the guards had been involved in numerous incidents of mass drinking, riotous behaviour, illegal shootings, suicides and rapes. In Maiguba, the guards had even called a collective strike for better living conditions and terms of employment. As a result, in the first four months of 1938, the BBK administration had issued no fewer than 1,526 reprimands to over a third of the guards. All this, the report concluded, had facilitated many escapes. ${ }^{178}$

175. NA RK, f. 865 , op. 32 ,d. 1/8, 1. 49; ibid., d. 9, 1. 48.

176. Cited in V. Semkin, “Belbaltlag: prikazi 1938," art. cit.: 3 .

177. V. N. Zemskov in V. B. Zhiromskaia, ed., Naselenie Rossii v XX veke..., op. cit.: 319.

178. VOKhR report, May 1938, GAOPDF RK, f. 38, op. 1, d. 13,11. 186-188. 
Nevertheless, Timofeev's policy paid dividends. In 1938 only 1,701 prisoners escaped ( $2 \%$ of the camp population) and all but 132 were recaptured. ${ }^{179}$ Moreover, the BBK over-fulfilled its felling plan by $20 \%$. The annual report of the BBK attributed this success to better "organisation of work," the elimination of seasonality and a doubling of the number of Stakhanovite prisoners. Plans for sawing timber, for furniture construction and for all other camp activities (except the plan for sewing shapki, which was fulfilled by 338\%) were, however, underfulfilled by extremely wide margins. ${ }^{180}$

\section{Retrenchment and rationalisation, 1938-1939}

From mid-1938, the Soviet regime made efforts to restrain the repressive dynamics unleashed the previous year. In November, L. P. Beria replaced Ezhov as People's Commissar of Internal Affairs. Thereafter, the NKVD Gulag sought to implement reforms on three fronts: to put a halt to arbitrary mass killings, to exploit its forced labour more efficiently and to rationalise the scope of its economic activities.

Beria's strategy of disentangling the complicitous NKVD-party alliance to establish a clearer division of functions between political and repressive organs led to the dissolution of the BBK Raikom in late 1938 and the re-establishment of a Politotdel within the camp, subordinate directly to the Moscow TsK. ${ }^{181}$ The new Narkom also took measures to extirpate the preceding generation of Gulag officials. In this, Beria was following precedent. In January 1938, Ezhov had already sacked Leningrad UNKVD boss Zakovskii and replaced the latter's 'client' Tenison with S. T. Matuzenko as Head of the Karelian UNKVD. 182 In March, the new Karelian security chief ordered the arrests of Tenison's appointees in the BBK, Deputy Chief of the Third Department A. F. Shondysh and Head of the Fifth Division of the Third Department I. A. Bondarenko, for having falsified investigations, mistreatment of prisoners and theft of property. In the course of 1938, numerous other Third Department officials associated with Tenison were arrested in connection with this case, including the mass murderer Matveev, chief investigator Dolinskii and the commander of the BBK SIZO M. A. Andrienko. Among specific charges, they were accused of having beaten prisoners to death

179. NA RK, f. 865 , op. 36, d. 14, 11. 1-10, reproduced in A. Iu. Zhukov et al., eds., Gulag v Karelii..., op cit.: 159-64. Overall in the Gulag, the number of escapes fell from 58,264 (6.4\% of the average annual population) in 1937 to $32,033(2.8 \%)$ in 1938 , indicating that the clampdown was centrally directed and universally applied, see GA RF, f. 9414, op. 1, d. 1155, 1. 2, cited in V. N. Zemskov in V. B. Zhiromskaia, ed., Naselenie Rossii v XX veke ..., op. cit.: 314.

180. GA RF,f. 9414,op. 1,d.1125,1.18.

181. GAOPDF RK, f. 38, op. 1, d. 16, 1. 429, cited in Ocherki istorii Karel'skoi organizatsii KPSS (Petrozavodsk: Kareliia, 1974), p. 309. No date given.

182. For NKVD networks, see A. A. Panchinskii, "Repressii v organakh NKVD v seredine 30kh godov," in Politicheskii sysk $v$ Rossii: istoria i sovremennost' (Sankt-Peterburg: SanktPeterburgskii gosudarstvennyi universitet, 1997): 284-294. 
with wooden poles and sharpened metal rods while carrying out executions in early 1938 at Sandormokh. ${ }^{183}$ The case, however, dragged on throughout the year without resolution. On 26 December 1938, Beria ordered the arrest of Matuzenko, denounced not only by Ezhov and his lieutenants for "antisoviet conspiracy," but also by a former comrade on the Karelian NKVD troika, Obkom secretary G. N. Kupriianov, for having directed a "massacre" of local cadres and having "shown gross indulgence towards the disgraceful work of the BBK Third Department."184 This event seems to have given new momentum to the BBK Third Department case: in May 1939, the Military Tribunal of the NKVD Forces sentenced all the defendants to death. In October, the executions were carried out in Petrozavodsk prison. ${ }^{185}$

Of course, Beria's reforms did not represent any genuine liberalisation of policy, but were intended to reassert and reinforce the Gulag's economic role as continuing arrests and national deportations further increased its population. In February 1939, the BBK leadership received a central directive "On dismissals of specialists in the Gulag," which noted that a large number of well-qualified prisoners had been purged during previous years from camp administrations as a "precautionary measure," and demanded that the arbitrary dismissal of good workers should cease. The directive also established a central register to record the names and skills of specialist prisoners within the Gulag system, in order to ensure they were correctly deployed to the camps where they could be of most use. ${ }^{186}$ At the same time, state security was a major consideration. In October, Beria issued a further order on the geographical distribution of prisoners by category of crime and by nationality. The most heinous political offenders were to be assigned to seven of the most remote and toughest camps (Kolyma, Norilsk, Vorkuta and four other camps in the Komi republic). Minority nationalities were to be transported to sites distant from their places of origin, so that, for example, it was forbidden to send Finns and Karelians to the $\mathrm{BBK}$ or other camps in the region. ${ }^{187}$

Beria was also concerned at the Gulag's low level of labour productivity. Under the Third Five-Year Plan, the camp system received twelve billion rubles' worth of economic tasks. To meet this challenge, the Narkom demanded in April 1939 that the camps should receive better supplies of food, clothing and machinery, and halt the practice of conditional pre-term release. As regarded food supplies, he wrote, prisoners received less than $70 \%$ of their designated daily ration of 2,000 calories, with the result that 200,000 inmates (approximately $15 \%$ of the total camp population) were currently classed as weak, and only about $65 \%$ of the camp

183. I. Chukhin, Kareliia-37 ..., op. cit.: 126-27.

184. Ibid.: $110,126$.

185. Ibid.: 127. For Matveev, see B. Ioffe, "Solovetskii rasstrel," ... art. cit.: 28-29. As nonpolitical cases, none has been subject to rehabilitation.

186. NKVD directive, 22 February 1939, NA RK, f. 865, op. 35, d. 1/1a, 1. 29.

187. NKVD directive, 10 October 1939, NA RK, f. 865, op. 35, d. 1/2a, 11. 340-341. 
population were fully productive. ${ }^{188}$ Pre-term release, in his opinion, "nullifie[d] the significance of corrective-labour measures, act[ed] contrary to the struggle versus crime and create[d] a high turnover of the camp population." He proposed to forbid this practice, and to offer prisoners more appropriate 'incentives' to work, in particular better rations for the most productive, and harsher punishments, including execution, for 'disorganisers.' In response, Union Procurator Vyshinskii noted that the number of pre-term releases was minimal (between October 1938 and January 1939, 1.3\% of the Gulag population and $0.75 \%$ of the BBK's population). ${ }^{189}$ People's Commissar of Justice N. M. Rychkov added that former prisoners had in any case to remain in the region of the camp for the remainder of their terms, so their labour was still available. ${ }^{190}$ Vyshinskii, however, supported Beria's call for the Gulag to shoot the worst offenders against labour discipline, while Rychkov insisted that only the courts could impose this sentence, and the camp administrations should confine themselves to punishing transgressors by solitary isolation, or by introducing a "tougher regime" and "worsened living conditions" (sic). The Sovnarkom's decision was to retain pre-term release, not to shoot prisoners for disciplinary violations and to improve supplies.

Thirdly, Beria rationalised the Gulag's economic activities, concentrating its resources on a smaller number of high priority projects, especially military construction work in the Far East and timber production, and divesting the camps of "inappropriate tasks."191 In March 1939, the BBK was accordingly subordinated to the Gulag Administration of the Timber Industry. ${ }^{192}$ In February 1941, the Combine was transferred out of the Gulag system altogether to the authority of the new NKVD Chief Administration of Timber Industry Camps, which BBK chief Timofeev was appointed to head, doubtless as a reward for his work in Karelia. ${ }^{193}$

By then, the BBK had already relinquished most of its secondary activities. In March 1939, it transferred the Belomor Canal to the People's Commissariat of Water Transport (Narkomvod), whose new chief was Ezhov. ${ }^{194}$ Later in the year, Narkomles took over management of the Segezha paper-pulp combine, after the BBK had completed building the main plant and taken measures to ensure that free

188. Letter of Beria to Molotov, 9 April 1939, GA RF, f. 5446, op. 23a, d. 121, 1. 9. For further details, see Sovnarkom Memorandum, 22 May 1939, ibid., 1. 11.

189. Letter of Vyshinskii to Molotov, 17 April 1939, ibid., 1.5.

190. Letter of Rychkov to Molotov, 20 April 1939, ibid., 11. $2-4$.

191. Letters of Beria to Molotov, 10 December 1938, in ibid., d. 59, 1. 18; and 24 April 1939, in ibid., d. 76,11. 6-9.

192. M. B. Smirnov, ed., Sistema ispravitel' no-trudovykh lagerei v SSSR ..., op. cit.: 162-163.

193. For Timofeev's appointment, see N. V. Petrov, K. B. Skorkin, Kto rukovodil NKVD, 1934-1941. Spravochnik (Moscow: Zven ia, 1999): 414. For details on establishment of GULLP, see Edwin Bacon, The Gulag at war. Stalin's forced labour system in the light of the archives (Basingstoke: Macmillan, 1994): 59; and M. B. Smirnov, ed., Sistema ispravitel'notrudovykh lagerei $v$ SSSR..., op. cit.: 111-112.

194. Letter of Molotov to Politbiuro, undated (early 1939), GA RF, f. 5446, op. 23a, d. 59, 1. 18. Sovnarkom resolution dated 23 March 1939, in ibid., 11. 19-20. 
personnel would work separately from the prisoners who remained to carry out subsidiary construction tasks. ${ }^{195}$ In October, the BBK handed over these prisoners to a newly established Segezha ITL. ${ }^{196}$

The BBK's most strikingly symbolic reform, however, occurred at the end of the year. In October, Beria wrote to Molotov requesting that the NKVD prison on Solovetskii Island be closed: the security police had sufficient prison capacity elsewhere and this facility cost about 14,000 rubles annually per prisoner, as opposed to less than 2,000 rubles in other prisons. He proposed that the islands be transferred to Karelian jurisdiction. ${ }^{197}$ At this point, Admiral N. G. Kuznetsov intervened to request that the islands should be transferred to the Northern Fleet, since they guarded the Belomor Canal's northern exit and the White Sea ports and flanked the Gulf of Kandalaksha. ${ }^{198}$ The Karelian leadership, by this time wholly preoccupied with the prospect of territorial expansion westwards, agreed to this measure, and the islands were transferred to the Navy's jurisdiction by a Sovnarkom decree of 25 November 1939. 199 This decision brought to an end sixteen years of terror on the Solovetskii islands.

Following the 1939-1940 Winter War, Moscow demonstrated a new enthusiasm for Karelian industrial development. The BBK, however, was not given a chance to participate in the realisation of its earlier visions. Throughout 1940, the Gulag administration transferred BBK prisoners working on newly-initiated construction projects to independent camp authorities. ${ }^{200}$ In early 1941, these camps were themselves removed from the Gulag system and subordinated to the new NKVD Chief Administrations. At the end of 1940, the Chief Administration of Camps of Hydroelectric Construction established at Matkozha a separate construction administration and camp to build the aluminium factory and hydroelectric plant which the BBK had originally planned in the early 1930's, but had shelved for lack of investment. ${ }^{201}$ In June 1941, the NKVD halted all its Karelian operations and evacuated the prisoner population eastwards before the advancing Finnish troops. ${ }^{202} \mathrm{~A}$ few months later, the BBK was finally dissolved. This was not the end of the Karelian Gulag, however: prisoners continued to work in the unoccupied

195. GA RF, f. 5446, op. 23a, d. 59,11. 8-9.

196. M. B. Smirnov, ed., Sistema ispravitel no-trudovykh lagerei v SSSR ..., op. cit.: 390.

197. Although the archipelago was in fact still within Arkhangelsk Oblast', despite the many Karelian requests for its transfer over the last two decades. Letter dated 26 October 1939, GA RF, f. 5446, op. 23a, d. 104, 11. 7-8.

198. Letter dated 29 October 1939, ibid.,11.3-4.

199. Ibid., 11. 1,8.

200. For Monchegorlag, see M. B. Smirnov, ed., Sistema ispravitel'no-trudovykh lagerei $v$ SSSR..., op. cit:: 327; for Kandalakshstroi, ibid.: 283; for Pudozhstroi, ibid.: 365.

201. Ibid., p. 321.

202. During the evacuation a large proportion of the BBK's archives sank, by accident or design, in Lake Onega, see V. Semkin, "Arkhipelag Belbaltlag," Leningradskaia pravda (17 June 1989): 3 . 
eastern districts, and following the war forced labour was deployed in renewed strength as the republic struggled to reconstruct its economy and infrastructure.

\section{Conclusion}

My earlier paper on the Karelian Gulag surveyed its expansion during the 1920's and early 1930's as a semi-autonomous institution, subordinated to state security policy and to the general principles of the plan, but "also defining its own economic role and the direction and shape of its own development in response to both central and regional opportunities." The Solovetskii camp had special status because of its pioneering role in the mass use of forced labour as a means of developing the state periphery. The Belomor Canal construction was a prestigious project which promised economic, strategic and propaganda benefits. The BBK was founded to permit the OGPU-NKVD to capitalise on its perceived success on the canal: with massive investment, it was to become a powerful industrial combine, acting as the Gulag's processing and distribution hub by uniting the remote camps of the Arctic and Far East with internal and global markets. This was the zenith of Iagoda's institutional and territorial empire-building.

During the Second Five-Year Plan, the Karelian Gulag relinquished its semiautonomous status and submitted to the political control and planning discipline of the centre. There were several aspects of this transformation. First, the BBK lost out on financial, material and labour resources within the Gulag system to other projects of greater perceived value, such as new canal and railway constructions. Secondly, the Gulag system itself was subordinated more strictly to Soviet investment priorities and the regional division of labour. The Second Five-Year Plan's retrenchment on new industrial expenditure, Karelia's strategic vulnerability and its competitive advantage in timber compelled the $\mathrm{BBK}$ to abandon its grand vision of regional industrial development and to specialise in timber production and processing. Within the Soviet system of resource allocation, any organisation which was not favoured for priority treatment - either within the economy as a whole or within one of its many sub-systems - was condemned to perpetual deficit management. The BBK's operations were thus, thirdly, subject to the normal constraints and distortions of a command system (labour shortages and high turnovers; delayed and inadequate funding; inter-enterprise indebtedness, etc.), as well as to the special problems of a forced labour institution (the costs of maintaining weak and non-working populations, and of excess mortality; dependence for labour on state security policy and lack of co-ordination between repressive and productive agencies; assuring discipline and productivity from an untrained and naturally recalcitrant workforce; subsidising guards, convoys and repressive apparat, etc.).

A fourth aspect of the BBK's transformation in the period under survey was its rapprochement with other regional authorities. The Karelian government, especially after Zhdanov's dismissal of the Red Finnish leadership, welcomed the 
camp's significant participation in the regional economy and tried to encourage its involvement in long-term development plans, in particular the colonisation of remote northern districts, though local officials still feared the prisoners' disorderly conduct and their political influence on the civil population. The Karelian party organisation, having long sought to subordinate the camp to its authority, now worked in increasingly close collaboration with the camp's officials, especially in party membership and disciplinary procedures. In 1936 and early 1937, the Karelian Obkom participated in the destruction of the BBK's judiciary and during the following eighteen months the regional secretaries sat on the NKVD troika which processed the BBK Third Department's case files. After Ezhov's dismissal, Beria intervened to end this lethal nexus between party and security organs, and to restructure the camp system and its operations in a more efficient and productive manner.

The OGPU-NKVD 'special' camp system, as a political institution, an economic agency and a cultural phenomenon, was an intrinsic element of Stalinism, and a defining moment in the evolution of the Soviet system. It not only reproduced and embodied many of the structures, practices and values of post-revolutionary reality, but acted as a formative influence on its further development. ${ }^{203}$ Regional case studies therefore not only afford insights into the operations of individual camp networks, and form the basis for new empirical and conceptual accounts of the Gulag's role in Soviet political, economic and social change, but also open valuable perspectives on the nature of the system as a whole. In the first paper, I cited the ominous words with which Chekist guards in 1928 greeted the young prisoner Dmitrii Likhachev into the world of the camps: "Zdes' vlast' ne sovetskaia, zdes' vlast' solovetskaia!" 204 Reconstructing the reciprocal, dynamic relationship between 'Solovetskii power' and 'Soviet power,' understood as two models of potential development, remains a crucial problem for the historiography of Stalinism.

Department of History

The University of Manchester

Oxford Road

Manchester M13 9PL

United Kingdom

npbaron@man.ac.uk

203. For the Gulag as microcosm of Soviet reality, see Mikhail Rozanov, Solovetskii Kontslager'v Monastyre, $1922-1939$ gg. Fakty. Domysly. "Parashi." Obzor vospominanii solovchan solovchanami $v d v u k h$ tomakh (authors's publication: 1979): 186-191. For example, Ivan Solonevich: "Everything that happens in the camp, happens also in freedom. And viceversa. But in the camp it is all just more obvious, simpler, clearer-cut."

204. "There's no Soviet power here, only Solovetskii power!" See D. S. Likhachev, Reflections on the Russian soul, op. cit.: 87. 